\title{
Factors for Measuring Photovoltaic Adoption from the Perspective of Operators
}

\author{
Felipe Moraes do Nascimento ${ }^{1, * \mathbb{C}}$, Julio Cezar Mairesse Siluk ${ }^{1}$, Fernando de Souza Savian ${ }^{1}{ }^{(\mathbb{D}}$, \\ Taís Bisognin Garlet ${ }^{2}$, José Renes Pinheiro ${ }^{3}$ and Carlos Ramos ${ }^{4}$ \\ 1 Department of Production and Systems, Federal University of Santa Maria (UFSM), \\ 97105-900 Rio Grande do Sul, Brazil; jsiluk@ufsm.br (J.C.M.S.); savian.fernando@gmail.com (F.d.S.S.) \\ 2 Department of Production and Transport Engineering, Federal University of Rio Grande do Sul (UFRGS), \\ 90035-190 Rio Grande do Sul, Brazil; tais_garlet@hotmail.com \\ 3 Department of Processing in Electrical Energy, Department of Electrical Engineering and Computing, \\ Federal University of Santa Maria (UFSM) and Federal University of Bahia (UFBA), 40210-630 Salvador, \\ Bahia,Brazil; jrenes@gepoc.ufsm.br \\ 4 Department of Informatics, Institute of Engineering, Polytechnic of Porto (ISEP/IPP), 4249-015 Porto, \\ Portugal; csr@isep.ipp.pt \\ * Correspondence: nfelipenascimento@gmail.com; Tel.: +55-54-996881810
}

Received: 23 March 2020; Accepted: 6 April 2020; Published: 15 April 2020

\begin{abstract}
The diffusion of photovoltaic distributed generation is relevant for addressing the political, economic, and environmental issues in the electricity sector. However, the proliferation of distributed generation brings new administrative and operational challenges for the sustainability of electric power utilities. Electricity distributors operate in economies of scale, and the high photovoltaic penetration means that these companies have economic and financial impacts, in addition to influencing the migration of other consumers. Thus, this paper aims to systematically identify and evaluate critical factors and indicators that may influence electricity distributors in predicting their consumers' adoption of photovoltaic technology, which were subjected to the analysis of 20 industry experts. Results show that the cost of electricity, generation capacity, and cost of the photovoltaic systems are the most relevant indicators, and it is possible to measure a considerable part of them using the internal data of the electricity distributors. The study contributes to the understanding of the critical factors for the forecast of the adoption of consumers to distributed photovoltaic generation, to assist the distribution network operators in the decision making, and the distribution sustainability. Also, it establishes the theoretical, political, and practical implications for the Brazilian scenario and developing countries.
\end{abstract}

Keywords: distributed generation; photovoltaic energy; photovoltaic adoption; distribution system operators; distribution sustainability

\section{Introduction}

Electricity is a determining factor for the quality of life in modern society [1], and it is the primary source for most industrial activities [2]. The dynamic economic development in the world has made a direct contribution to increasing energy demand [3], and in the past years, the relation between energy consumption and economic variables has been observed by economists and policymakers [4]. Besides that, there is a broad consensus on the need for political actions and an intense debate on mitigation measures of such changes to mitigate the effects of climate change [5]. The undeniable need to reduce greenhouse gas emissions and the transition to cleaner electricity generation has led to an unavoidable requirement for new regulations and mechanisms to promote the growth of renewable 
energy [6]. This movement seeks an economy focused on sustainability, intending to achieve energy security and environmental protection [7], instead of relying on sources difficult access and exhaustible.

In this context, the Brazilian electric sector is undergoing a transformation marked by the entry of mini and micro distributed generation years after the perception of these changes in Europe, making the diffusion and the competitive substitution of energy technologies substantially affect the dynamic evolution of the structure of the electrical sector [8]. In this way, solar energy stands out in the transition from non-renewable electricity generation to renewable energy, especially regarding the distributed generation. Among the countries with the highest generation capacity, Brazil stands out in solar energy due to its large geographical area with favorable conditions and high irradiation rates [9]. Furthermore, the photovoltaic generation has a highly competitive potential within the energy scenario [10]. However, operational characteristics are not adapted to this imminent change. Technical issues related to voltage control, power flow inversion, and increased losses should be considered in the investment decisions of the distributors, including the adaptation of the physical network and the development of smart grids [11]. With the increase in the capture of photovoltaic energy, there has been an increase in negative impacts on the revenue of utility companies in several countries, such as the United States [12-14] and Europe [15,16].

Utilities have faced the perspective that customers will reduce their electricity purchases as they adopt solar photovoltaic generation and may enter a positive feedback loop (spiral of death) [17]. Finding financial balance can be a problem, as consumers subsidize solar energy adopters, who transfer costs to other network participants [18]. It should be noted that distributed generation challenges the very nature of the natural monopoly of electricity distribution concessionaires. Currently, consumers who opt for a distributed generation still rely on the electricity supply of the energy distributors in the moments that their system is not in operation, leading the system operator to assume the technical responsibility for those systems [19] and mitigate economical and financial impacts. Distribution system operators can avoid high costs and reduced revenues if they understand the motivators for consumers to join the photovoltaic system [17]. In this context, understanding how photovoltaic energy has been spreading can be a competitive advantage for distribution system operators [20].

The consumer can perceive photovoltaic technology as social status, related to personal gains and external perceptions [21]. The different behavioral aspects give new meaning to the consumer's relationship with energy, which has implications mainly for the relationship between the consumer and the distribution system operators. Different perspectives approach this relation: Politics and regulation [22-24], demand and electrical networks [25-29], prices and markets [30-32], and impacts and diffusion [33-36]. It is noteworthy that the literature highlights the importance of consumer heterogeneity and the existence of behavioral factors that should not be ignored by the distribution system operators, especially concerning photovoltaic adoption. Therefore, it is necessary to understand what these factors are and how they can be used to assist system operators in the search for a more sustainable distribution.

Aspects of the adoption of new technologies have been of great interest to different areas of research [37]. Diffusion is frequently used to explain the motivators that lead agents in society to adopt a new technology or replace an obsolete technology with an updated one [38,39]. In the field of distributed photovoltaic generation, the diffusion process stands out mainly for its economic and environmental issues, contrary to traditional generation systems [40], involving uncertainties that relate to technological and social aspects [41]. The dissemination of photovoltaic systems can be considered as a problem of diffusion of innovations [42], as established by Refs. [43,44]. In this perspective, it is emphasized that the importance that people's adoption of technology represents the understanding of photovoltaic diffusion. According to Refs. $[27,28]$, the decision-making process regarding the acquisition of a new technology consists of five steps. The first step is knowledge, that is when the person is introduced to technology and understands its operation. The second step is persuasion, which occurs when the person takes a favorable or unfavorable attitude towards the product. The third step is called the decision, which happens when the client engages in activities that lead to a choice: 
To adopt or reject the innovation. The fourth stage is called the implementation, and it happens when the individual starts using some technology. The fifth phase is the confirmation that the person aims to strengthen an innovation decision that has already been made. This process is linked to factors that influence the clients in each of the decision-making phases to adopt technological innovations such as photovoltaic systems.

The factors of acquisition of photovoltaic technology are structured from characteristics and aspects that influence the customer to adopt distributed photovoltaic generation. These aspects are presented in different ways in the literature, but generally demonstrate a strong relationship between the economic influence perceived by individuals and their behavioral issues. It acquires a system related to aspects of people's economic and behavioral viability. The adoption factors can be observed in the academic literature, as in Ref. [45], who applied a new analytical approach to 13 international case studies, providing a systematization of policies and regulatory adjustments for diffusion. The authors of [46] assessed the factors influencing the spread of photovoltaic solar systems on the rooftops by 2050 in Switzerland. In the United States, Ref. [47] applied a spaced-based approach to investigate and quantify the influence of a built environment in urban areas on new clients. At the same time, Ref. [48] assessed the spatial distribution of solar photovoltaic adoption in the state of Georgia. The authors of Ref. [49] analyzed the diffusion and adoption of solar energy conversion in Greece over the last 40 years, and Ref. [50] explored the attitude of consumers of photovoltaic systems connected to buildings in Taiwan. The authors of Ref. [51] used the postal code data from 83 cities to investigate the influence of environmental, economic, social, and local variables on the spatial distribution of photovoltaic generation in urban areas of China. The authors of Ref. [52] analyzed the effect of social influences concerning economic and ecological issues in the adoption of photovoltaic technology in Germany. Additionally, studies examined factors and their impact on the acquisition of solar renewable energy technologies for urban households in Mexico [53] and identified the determinants of photovoltaic energy acquisition in Belgium [54]. In the Flanders region, Germany, and Canada, the study by Ref. [55] used Agent-Based Models (ABMs) to study and contrast the projected acquisition of photovoltaic systems and integrated batteries.

In Italy, Ref. [56] studied how support changes affect photovoltaic diffusion, while in Poland, an approach was developed to examine the reasons for rural family decisions for adhering to photovoltaic technology [57]. In Brazil, studies have been conducted on photovoltaic generation scenarios, opportunities, challenges, and panoramas [58-60], and also the diffusion to this technology and barriers to its accession [61]. Thus, it is possible to observe that the literature presents different analyses, seeking to understand specific aspects for the investigation of adoption and growth of photovoltaic diffusion in environmental, technical, political, economic, and social dimensions in isolation or in combination way $[37,40,61-65]$. Therefore, none of the studies presented the same focus of this article, highlighting the uniqueness of this research.

Some researchers claim that increasing the share of photovoltaic energy in the energy matrix is a complex process since the active acquisition of innovation involves several interconnected factors $[66,67]$. Thus, this article aims to identify the critical factors that may influence distribution system operators in predicting their customers' adoption of photovoltaic systems. A systematic review of the literature was made to achieve the article's objective and to measure the relevance of each factor through a qualitative study with experts from the Brazilian electricity sector. It is noteworthy that the indicators are raised from the perspective of the electricity sector agents, without the interference of consumers, so that they can anticipate the events related to public policies by the regulators and the issues of economic and financial impacts by electricity distributors. Therefore, the study contributes to the understanding of the most relevant factors that must be considered by the distribution system operators to predict the adoption of photovoltaic technology by their consumers, and to the knowledge if these factors are suitable for use in the Brazilian scenario. Thus, it is possible to assist distribution companies in decision making, aiming at reducing the impacts caused by the diffusion of this technology. Also, 
the article provides a discussion about the photovoltaic spread in Brazil and in emerging economies or regions where the implementation of photovoltaic systems is still incipient.

This article is structured into five sections. Section two presents the research methods, describing the necessary steps to conduct the systematic review and the qualitative study. Chapter three introduces the factors identified for predicting the adoption of photovoltaic systems from the perspective of distribution system operators. Section four provides the description of the interviews that were carried out and the analysis of the information obtained, while chapter five sets out the final considerations, emphasizing the implications of the study.

\section{Methods}

This study is structured into four steps. In the first stage, adherence prediction factors were identified through a systematic review in the Scopus and Web of Science databases. In the next step, through a qualitative exploratory approach, structured interviews were performed with 20 specialists from different areas associated with the electricity sector. The sample included professionals such as consultants, researchers, analysts, politicians, and professionals from the distribution and generation sector, as well as technical managers from photovoltaic companies. This step was designed to ensure that a broad range of factors related to the prediction of adoption to photovoltaic technology was identified and evaluated from different perspectives. Therefore, it is possible to assist distributors in their decision making, since the existing scientific literature tends to focus on technical and economic aspects of the photovoltaic market, with little emphasis on other elements of accession. In the third step, the factors were structured in terms of their importance, according to the experts' evaluation. The fourth step involved the analysis of the interviews by comparing the expert opinions with the relevance of each factor.

\subsection{The Protocol of Systematic Review}

The research method was based on a systematic review of the literature. According to Ref. [68], systematic reviews differ from traditional narrative reviews by adopting a replicable, scientific, and transparent process. The review was based on the Preferred Reporting Items for Systematic Reviews and Meta-Analyses (PRISMA) [69] review protocol and aimed to identify the main predictors of consumer accession to photovoltaic systems. A skim-reading was done using books, reports from government agencies, international energy agencies, and scientific articles to delimit the research theme. The research question raised was: "What are the main factors for forecasting consumer adoption of the photovoltaic systems?". Scopus and Web of Science databases were selected to research since they include the leading publishers.

The search was conducted in May 2019 by three researchers in journals and conference proceedings for research and review papers in the selected databases, so the study becomes more comprehensive, and the results reveal the breadth of scientific research in the area. As the scope of the present factor for the search terms, the title, abstract, and keywords of the articles were selected, and a period no longer than 2012 to the present was stipulated since this was the year of publication of the first normative resolution on photovoltaic distributed generation in Brazil [70]. Furthermore, only complete articles longer than four pages and written in English, Portuguese, and Spanish were considered. The search string was defined as: title-abstract-keywords ("photovoltaic" OR "solar energy" OR "solar home system") AND title-abstract-keywords ( "adoption" OR "diffusion" OR "expansion" OR "motivat") AND title-abstract-keywords ( "prediction*" OR "monitoring*" OR "estimat" OR "projection*") AND title-abstract-keywords ( "insert" OR "penetration*" OR "decision*" OR "behavior" OR "adhesion*" OR "incentive *" OR "stimulus*" OR "promotion*" OR "impulse"

After searching in the Scopus and Web of Science databases, it was found that there was a significant body of works in the area of accession to photovoltaic systems. The database search resulted in a total of 325 articles, including duplicate materials. Then, to select only papers related to the topic under study, the following exclusion criteria were used: Articles that do not show synergy with 
the research question by reading the title and abstract; and duplicate articles in the two databases considered. The inclusion of specific articles related to the research question was also carried out through the complete reading of the materials. After applying these filters, 52 papers were obtained, which were subjected to a fluctuating reading to verify if they are related to the research question. The number of selected articles and the flow of the systematic review is shown in Figure 1.

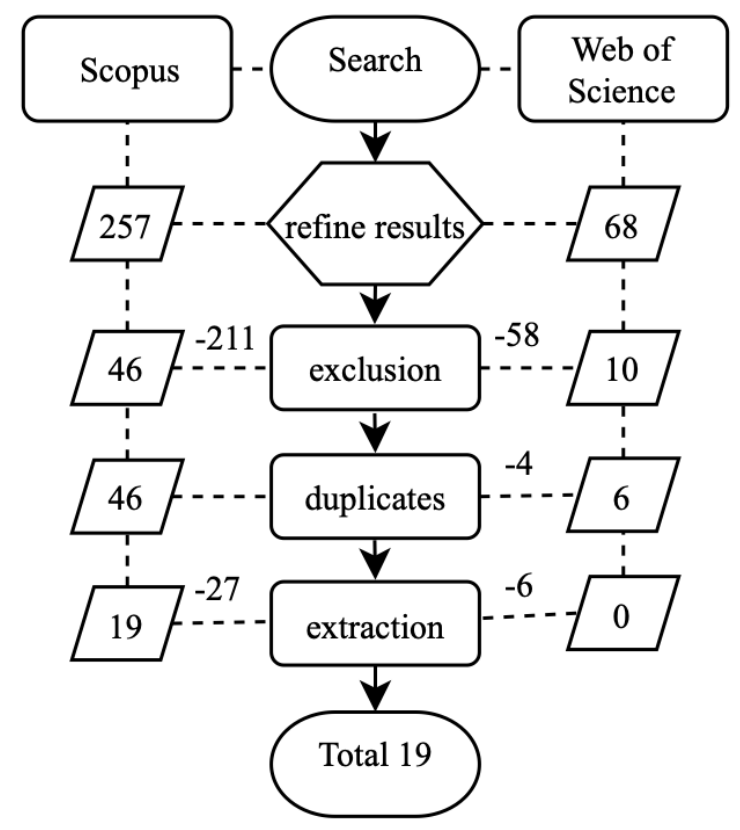

Figure 1. Systematic review steps.

The 52 articles were analyzed to verify if they presented any factor that influences the adoption of photovoltaic systems, resulting in 19 articles for analysis and data extraction that met the objective of the study. The 19 articles were read in full to explore the explanatory variables of the prediction of consumers' adoption to photovoltaic technology by the electricity distribution companies. This step consisted of analyzing the content of any material communicated by classifying, tabulating, and evaluating their main symbols and themes to verify their meaning [71]. Therefore, a database was built to store the information about the factors extracted from each article. The results were grouped by repetition and similarity according to the criterion of at least three citations per factor.

\subsection{Conducting Data Collecting from Interviews}

The structure proposed by Ref. [72] was followed to conduct the interviews, where the identified factors were grouped into topics for the construction of a questionnaire. The questions were tested and validated by specialists before being sent to the respondents to ensure that they achieved the research goals. The group of specialists involved two professors with PhDs in Electrical Engineering, one professor with a PhD in Production Engineering, two electrical engineers with master's degrees in Production Engineering, and three master's degrees in Production Engineering developing researches related to photovoltaic energy. Data collection was made online between June and July 2019, and it was based on structured interviews with key players of the Brazilian electricity sector with knowledge about the photovoltaic scenario. The interviews were developed into two stages. The first was based on the experts' classification of factors, and the second consisted of subjective questions to highlight the interviewees' personal and professional opinion on the topic to gain insights and knowledge about the industry characteristics based on individual experience.

Twenty interviews were completed with experts in the field, involving different topics related to the photovoltaic system, cost-benefit, profile, and life standard, as well as two questions that addressed their opinions about photovoltaic diffusion and the topics and proposed factors. This collection 
instrument is available in the Appendix A, and it was developed to fill the gap in Brazil and in emerging economies, which consists of a lack of comprehensive information about the characteristics and critical variables to forecast adoption to photovoltaic technology.

\section{Description of Results}

An approach was used considering the exploratory character of the research, involving a systematic literature review for the identification of factors and structured interviews conducted online. The interviews for this study were carried out with specialists who were involved in a decision-making process related to the forecast of adoption to photovoltaic technology, trying to understand whether the identified factors were adequate for measuring photovoltaic adoption from the perspective of electricity distributors. The structure of the interviews was divided into two parts. In the first one, the interviewees classified the topics and indicators created from the factors at the level of relevance. In the second one, interviewees answered two questions instinctively.

\subsection{Description of the Results of the Systematic Review}

Based on the methodology of a systematic literature review, a detailed analysis was carried out with published articles aimed at predicting the diffusion and acquisition of consumers for photovoltaic technology. For this, 23 factors were identified that could be used by electricity distributors to predict the adoption of photovoltaic systems from information obtained directly from their databases. During the analysis process, the variables used in the decision making of the published papers were listed and grouped into four topics and 12 indicators. The first topic was called the photovoltaic system, which consisted of the estimated generation indices, technical parameters, and system cost. The second one was called cost-benefit, which contained the cost of electricity indicators, incentive programs, and interest rates (the two first topics are referring to economic viability). The third topic was called profile, which addressed the indices of environmental concern, customers' knowledge, and the influence of other agents. The last one is called the life standard, which involves the indices of lifestyle, residential, and housing value (the previous two items are referring to behavioral viability). In Table 1, it is possible to see the factors listed and classified from their topics and indexes together with the authors who used them for their studies.

Table 1. Factors identified in the literature, organized into topics and indicators.

\begin{tabular}{|c|c|c|c|c|}
\hline Topic & Indicator & Factor & Description & References \\
\hline \multirow{4}{*}{$\begin{array}{c}\text { Photovoltaic } \\
\text { system (economic } \\
\text { viability) }\end{array}$} & \multirow{3}{*}{$\begin{array}{l}\text { Estimation of } \\
\text { generation }\end{array}$} & Solar incidence & $\begin{array}{c}\text { Amount of } \\
\text { sun-radiated } \\
\text { energy at that } \\
\text { location }\end{array}$ & {$[56,63,67,73-80]$} \\
\hline & & Coverage area & $\begin{array}{c}\text { Roof area where } \\
\text { generation is or can } \\
\text { be installed }\end{array}$ & {$[56,73,75-77,80-82]$} \\
\hline & & Location & $\begin{array}{l}\text { Geographic } \\
\text { localization of } \\
\text { consumer unit }\end{array}$ & {$[56,63,67,73,74,80,81]$} \\
\hline & $\begin{array}{c}\text { Technical } \\
\text { parameters }\end{array}$ & Technical aspects & $\begin{array}{l}\text { Power, efficiency } \\
\text { and number of } \\
\text { modules that can } \\
\text { be installed in the } \\
\text { consumer unit }\end{array}$ & {$[56,63,67,73-75,77-80,82,83]$} \\
\hline
\end{tabular}


Table 1. Cont.

\begin{tabular}{|c|c|c|c|c|}
\hline Topic & Indicator & Factor & Description & References \\
\hline & & Equipment lifetime & $\begin{array}{c}\text { Service life and } \\
\text { durability of } \\
\text { photovoltaic } \\
\text { modules }\end{array}$ & {$[63,67,73,76-79]$} \\
\hline & & $\begin{array}{l}\text { Module } \\
\text { Positioning }\end{array}$ & $\begin{array}{l}\text { Tilt, elevation and } \\
\text { shading of PV } \\
\text { modules }\end{array}$ & {$[63,73,75,76,78,79]$} \\
\hline & & $\begin{array}{l}\text { System investment } \\
\text { cost }\end{array}$ & $\begin{array}{c}\text { Investment cost in } \\
\text { photovoltaic } \\
\text { equipment }\end{array}$ & {$[56,63,67,74,76-78,83-86]$} \\
\hline & System cost & $\begin{array}{c}\text { System Operating } \\
\text { Cost }\end{array}$ & $\begin{array}{c}\text { Maintenance and } \\
\text { operation costs of } \\
\text { the photovoltaic } \\
\text { system }\end{array}$ & {$[56,63,67,77,78,84,86,87]$} \\
\hline \multirow{4}{*}{$\begin{array}{c}\text { Cost-benefit } \\
\text { (economic viability) }\end{array}$} & \multirow{2}{*}{$\begin{array}{l}\text { Cost with } \\
\text { electricity }\end{array}$} & $\begin{array}{c}\text { Electricity } \\
\text { consumption }\end{array}$ & $\begin{array}{c}\text { Electricity } \\
\text { consumption of the } \\
\text { consumer unit }\end{array}$ & {$[63,73,74,77-81,83,85]$} \\
\hline & & Electricity tariff & $\begin{array}{l}\text { Energy charge } \\
\text { applied by the } \\
\text { electricity } \\
\text { distributor }\end{array}$ & {$[56,63,67,74,77-80,83,85,87]$} \\
\hline & $\begin{array}{l}\text { Incentive } \\
\text { program }\end{array}$ & $\begin{array}{l}\text { Government } \\
\text { incentives and } \\
\text { discounts }\end{array}$ & $\begin{array}{c}\text { Government } \\
\text { programs and } \\
\text { discounts from PV } \\
\text { companies }\end{array}$ & {$[67,76,77,83-85,87]$} \\
\hline & Interest rates & Bank charges & $\begin{array}{l}\text { Interest rates } \\
\text { applied by banks } \\
\text { and credit } \\
\text { companies }\end{array}$ & {$[67,77,83]$} \\
\hline \multirow{4}{*}{$\begin{array}{c}\text { Profile (behavioral } \\
\text { viability) }\end{array}$} & $\begin{array}{l}\text { Environmental } \\
\text { concern }\end{array}$ & $\begin{array}{l}\text { Environmental } \\
\text { concern }\end{array}$ & $\begin{array}{l}\text { Concern for the } \\
\text { environment and } \\
\text { climate change }\end{array}$ & {$[56,67,86-88]$} \\
\hline & $\begin{array}{l}\text { Consumer } \\
\text { knowledge }\end{array}$ & $\begin{array}{l}\text { Consumer } \\
\text { knowledge }\end{array}$ & $\begin{array}{c}\text { Consumer } \\
\text { knowledge of } \\
\text { photovoltaic } \\
\text { technologies, their } \\
\text { benefits, regulation } \\
\text { and market }\end{array}$ & {$[67,83,88,89]$} \\
\hline & \multirow[b]{2}{*}{$\begin{array}{l}\text { Influence of } \\
\text { other agents }\end{array}$} & Agent Interactions & $\begin{array}{c}\text { Influence of people } \\
\text { adept at } \\
\text { photovoltaic } \\
\text { technology }\end{array}$ & {$[63,67,74,83]$} \\
\hline & & $\begin{array}{l}\text { Nearby installed } \\
\text { units }\end{array}$ & $\begin{array}{l}\text { Influence due to } \\
\text { proximity effect } \\
\text { with consumers } \\
\text { who already have } \\
\text { photovoltaic } \\
\text { technology }\end{array}$ & {$[63,73,74,81,83,85,87]$} \\
\hline \multirow{2}{*}{$\begin{array}{l}\text { Life standard } \\
\text { (behavioral } \\
\text { viability) }\end{array}$} & \multirow[t]{2}{*}{ Lifestyle } & Average income & $\begin{array}{l}\text { Income, } \\
\text { consumption } \\
\text { behavior of } \\
\text { residents of the } \\
\text { consuming unit }\end{array}$ & {$[56,67,73,74,80-82,85]$} \\
\hline & & Lifestyle habits & $\begin{array}{c}\text { Consumer unit } \\
\text { resident lifestyle } \\
\text { and household } \\
\text { data }\end{array}$ & {$[56,63,67,73,75,76,80,81,88]$} \\
\hline
\end{tabular}


Table 1. Cont.

\begin{tabular}{|c|c|c|c|c|}
\hline Topic & Indicator & Factor & Description & References \\
\hline & \multirow[b]{2}{*}{ Residential } & $\begin{array}{l}\text { Number of } \\
\text { residents }\end{array}$ & $\begin{array}{l}\text { Total number of } \\
\text { residents in the } \\
\text { consuming unit }\end{array}$ & {$[63,73,77,81,82,85,88]$} \\
\hline & & Residential data & $\begin{array}{l}\text { Geo-economic data, } \\
\text { number of cars, } \\
\text { televisions among } \\
\text { others }\end{array}$ & {$[56,63,67,73,75,76,80,81,88]$} \\
\hline & \multirow{3}{*}{ Housing value } & Cost of ownership & $\begin{array}{l}\text { Market value of the } \\
\text { place where the } \\
\text { consumer unit is } \\
\text { located }\end{array}$ & {$[63,73,76,81,85]$} \\
\hline & & Building area & $\begin{array}{l}\text { Constructed area } \\
\text { where the } \\
\text { consumer unit is } \\
\text { allocated }\end{array}$ & {$[63,73,74,76,78,80,83,85,88]$} \\
\hline & & Address & $\begin{array}{l}\text { Address, street, } \\
\text { neighborhood of } \\
\text { consumer unit }\end{array}$ & {$[56,63,67,73,74,80,81]$} \\
\hline
\end{tabular}

It can be observed that some factors do not influence the prediction of consumers' decision making. Still, when grouped, they form typical indicators that can produce vital knowledge to assist distribution system operators in predicting consumers' decision to purchase a photovoltaic system.

\subsection{Description of the Interview Results}

Table 2 shows the profile of the interviewees who were selected to compose the research sample. The "Ai" codes were used for planning analysts; "Ci" for energy utility professionals; "Gi" for the government member; "Ei" to the energy consultant; "Mi" for market price analysts; "Ri" for the energy researcher, and "Ii" for professionals from photovoltaic companies, to preserve the identity of them and possible conflicts of interest. The sample was constituted of 20 people. Four of them were energy researchers, which included two students, one researcher from a research center, and one from an electrical company. Also, there were five energy, structural, and technological planning analysts, three energy concessionaire professionals, one electrical consultant, three market price analysts, a member of the government, and three professionals from companies of the photovoltaic sector.

Table 2. Profile of respondents.

\begin{tabular}{cc}
\hline Code & Profile \\
A1 & $\begin{array}{r}\text { Bachelor of Electrical Engineering, with a master's degree in Photovoltaic Energy. He has } \\
\text { over six years of experience and is currently part of the Energy Research Company (EPE), } \\
\text { linked to the Brazilian Ministry of Mines and Energy, working in energy planning studies } \\
\text { and topics related to photovoltaic generation. }\end{array}$ \\
A2 & $\begin{array}{r}\text { Bachelor of Mechanical Engineering, with a master's degree in Urban and Environmental } \\
\text { Engineering. He has over eleven years of experience and is currently part of the Energy } \\
\text { Research Company, acting as a technical consultant in studies associated with } \\
\text { electricity auctions. }\end{array}$ \\
A3 & $\begin{array}{r}\text { Bachelor of Computer Engineering, has over 10 years of experience and is currently part of } \\
\text { the Brazilian Micro and Small Business Support Service (SEBRAE), working with Analytics, } \\
\text { Business Intelligence, Foresight, and Global Indicators. }\end{array}$ \\
A4 & $\begin{array}{l}\text { Bachelor of Architecture, with master and doctorate in Civil Engineering in the area of } \\
\text { energy efficiency. He has over 11 years of experience and is currently an infrastructure } \\
\text { analyst at the Brazilian Ministry of Environment and Climate Change and Mitigation } \\
\text { Policy Coordinator. }\end{array}$ \\
\hline
\end{tabular}


Table 2. Cont.

\begin{tabular}{|c|c|}
\hline Code & Profile \\
\hline A5 & $\begin{array}{l}\text { Bachelor of Civil Engineering, with a master's degree in Sanitation, Environment and } \\
\text { Water Resources. He has more than six years of experience and is currently part of the } \\
\text { Chamber of Electric Energy Commercialization, working on projects involving analysis } \\
\text { and consistency of hydrological and climatological information. }\end{array}$ \\
\hline $\mathrm{C} 1$ & $\begin{array}{l}\text { Bachelor of Production Engineering, with a master's degree in Industrial Systems and } \\
\text { Processes. He has over } 18 \text { years of experience and currently operates in the area of } \\
\text { electricity transmission in a concessionaire in southern Brazil. }\end{array}$ \\
\hline $\mathrm{C} 2$ & $\begin{array}{l}\text { Bachelor of Business Administration, has over } 18 \text { years of experience and is currently part } \\
\text { of a dealership, working with business management and new renewable ventures. }\end{array}$ \\
\hline $\mathrm{C} 3$ & $\begin{array}{l}\text { Electrical technologist, has over } 17 \text { years of experience and is currently part of a midsize } \\
\text { dealership in southern Brazil, working in technical planning. }\end{array}$ \\
\hline E1 & $\begin{array}{l}\text { Bachelor of Electrical Engineering, has over } 40 \text { years of experience and is currently part of a } \\
\text { research center, where he acts as a senior consultant in the areas of design, audit and } \\
\text { consulting in Electrical Engineering, with emphasis on Power Systems. }\end{array}$ \\
\hline G1 & $\begin{array}{l}\text { Bachelor of Laws, Member of Government. He has more than one year of experience and is } \\
\text { currently a state deputy at the Legislative Assembly of the State of Rio Grande do Sul, } \\
\text { working on projects such as the privatization of the electricity sector. }\end{array}$ \\
\hline I1 & $\begin{array}{l}\text { Bachelor of Electrical Engineering, with aa postgraduate degree in Photovoltaic Solar } \\
\text { Energy. She has over six years of experience and is currently a partner-owner of a project } \\
\text { integrator and installation of photovoltaic systems. }\end{array}$ \\
\hline I2 & $\begin{array}{l}\text { Bachelor of Electrical Engineering, has more than three years of experience and is currently } \\
\text { a partner-owner of a project integrator and installation of photovoltaic systems. }\end{array}$ \\
\hline I3 & $\begin{array}{l}\text { Bachelor of Metallurgical Engineering, has over three years of experience and is currently } \\
\text { director of a renewable development and deployment company. }\end{array}$ \\
\hline M1 & $\begin{array}{l}\text { Bachelor of Electrical and Energy Engineering, has over three years of experience and is } \\
\text { currently part of Electra Energy, where he works as a trader in the trading of electricity in } \\
\text { the free market. }\end{array}$ \\
\hline M2 & $\begin{array}{l}\text { Bachelor of Energy Engineering, has more than two years of experience and is currently } \\
\text { part of the Chamber of Electric Energy Commercialization, where he works with energy } \\
\text { planning studies, calculations and projections of energy prices. }\end{array}$ \\
\hline M3 & $\begin{array}{l}\text { Bachelor of Energy Engineering, has more than five years of experience and is currently } \\
\text { part of the Chamber of Electric Energy Commercialization, where he works with energy } \\
\text { planning studies, calculations and projections of energy prices. }\end{array}$ \\
\hline $\mathrm{R} 1$ & $\begin{array}{c}\text { Bachelor of Mechanical Engineering, Master of Mechanical Engineering. He has over four } \\
\text { years of experience and is currently an energy researcher at a private university in } \\
\text { southern Brazil. }\end{array}$ \\
\hline $\mathrm{R} 2$ & $\begin{array}{l}\text { Bachelor of Chemistry, with a master's degree in Electrochemistry. He has over } 30 \text { years of } \\
\text { experience and is currently part of a private research center working on topics such as } \\
\text { power accumulators for electric grids and electric cars. }\end{array}$ \\
\hline $\mathrm{R} 3$ & $\begin{array}{l}\text { Bachelor of Electrical Engineering, PhD in Electrical Engineering. He has over } 10 \text { years of } \\
\text { experience and currently works as a researcher at a federal university in southern Brazil, } \\
\text { working in the areas of systems control and photovoltaic generation. }\end{array}$ \\
\hline $\mathrm{R} 4$ & $\begin{array}{c}\text { Bachelor of Electrical Engineering, with master and doctorate in Planning of Energy } \\
\text { Systems. He has over eight years of experience and is currently part of the Chamber of } \\
\text { Electric Energy Commercialization, where he works with research and } \\
\text { development projects. }\end{array}$ \\
\hline
\end{tabular}

The selection of interviewees was made intentionally by selecting professionals with different profiles related to areas of technology, politics, and energy from different regions of Brazil, taking into account that they are involved in the process of generation, transmission, distribution, and commercialization of electricity, and distributed generation of photovoltaic energy. The sample 
includes professionals, researchers, and specialists from different sectors of society, bringing together diverse perspectives in the same context. The authors of Ref. [90] state that a survey with participants holding characteristics that are highly specific for the study aim requires a less extensive sample to offer sufficient information power. In this research, it can be highlighted that the interviewees work in institutions of high reputation and strategic impact in Brazil, such as EPE, SEBRAE, Brazilian Ministry of Environment, Legislative Assembly of Rio Grande do Sul, Federal Universities, and companies, among others. It is also noteworthy that they have over 10 years of experience on average. Thus, the sample is quite representative, and it allows significant conclusions for this study. The results obtained through the systematic identification of factors and the structured interviews with electricity sector specialists are presented and discussed in the following subsections. In the process described in Section 2.1, 19 studies were identified as directly linked to the prediction of consumer adoption to photovoltaic technology, which was used to determine the most relevant elements for forecasting the accession. The results obtained by applying the methodological procedures are fully described in the following subtopics.

\subsubsection{Description of the Results of Relevance Degree of the Indicators}

The 20 interviewees were asked about the relevance of each indicator. For each response option, a value from 1 to 5 was assigned, with 1 being the value for "Irrelevant" and 5 for "Very relevant". The value assigned on the scale was multiplied by the percentage of respondents for each answer option. Then, the values obtained were added to calculate the percentage relevance index for each indicator. This calculation helped to understand the importance of the indicators to predict the adoption of photovoltaic technology. From these questions, it was possible to identify which elements are considered indispensable to predict consumer adoption. The results are shown in Table 3.

Table 3. Degree of relevance of indicators according to respondents.

\begin{tabular}{|c|c|c|c|c|}
\hline Topic & Indicator & $\begin{array}{l}\text { Relevance of } \\
\text { Indicator }\end{array}$ & Answer Options & $\begin{array}{c}\text { Percentage of } \\
\text { Answers }\end{array}$ \\
\hline \multirow{15}{*}{$\begin{array}{c}\text { Photovoltaic } \\
\text { system }\end{array}$} & \multirow{5}{*}{$\begin{array}{l}\text { Estimation of } \\
\text { generation }\end{array}$} & \multirow{5}{*}{$85.00 \%$} & Irrelevant & $0.00 \%$ \\
\hline & & & Little relevant & $0.00 \%$ \\
\hline & & & Indifferent & $10.00 \%$ \\
\hline & & & Relevant & $55.00 \%$ \\
\hline & & & Very relevant & $35.00 \%$ \\
\hline & \multirow{5}{*}{$\begin{array}{c}\text { Technical } \\
\text { parameters }\end{array}$} & \multirow{5}{*}{$84.00 \%$} & Irrelevant & $0.00 \%$ \\
\hline & & & Little relevant & $0.00 \%$ \\
\hline & & & Indifferent & $5.00 \%$ \\
\hline & & & Relevant & $70.00 \%$ \\
\hline & & & Very relevant & $25.00 \%$ \\
\hline & \multirow{5}{*}{ System cost } & \multirow{5}{*}{$92.00 \%$} & Irrelevant & $0.00 \%$ \\
\hline & & & Little relevant & $0.00 \%$ \\
\hline & & & Indifferent & $5.00 \%$ \\
\hline & & & Relevant & $30.00 \%$ \\
\hline & & & Very relevant & $65.00 \%$ \\
\hline
\end{tabular}


Table 3. Cont.

\begin{tabular}{|c|c|c|c|c|}
\hline Topic & Indicator & $\begin{array}{l}\text { Relevance of } \\
\text { Indicator }\end{array}$ & Answer Options & $\begin{array}{c}\text { Percentage of } \\
\text { Answers }\end{array}$ \\
\hline \multirow{15}{*}{ Cost-benefit } & \multirow{5}{*}{$\begin{array}{l}\text { Cost with } \\
\text { electricity }\end{array}$} & \multirow{5}{*}{$95.00 \%$} & Irrelevant & $0.00 \%$ \\
\hline & & & Little relevant & $0.00 \%$ \\
\hline & & & Indifferent & $0.00 \%$ \\
\hline & & & Relevant & $25.00 \%$ \\
\hline & & & Very relevant & $75.00 \%$ \\
\hline & \multirow{5}{*}{ Incentive program } & \multirow{5}{*}{$80.00 \%$} & Irrelevant & $0.00 \%$ \\
\hline & & & Little relevant & $5.00 \%$ \\
\hline & & & Indifferent & $15.00 \%$ \\
\hline & & & Relevant & $55.00 \%$ \\
\hline & & & Very relevant & $25.00 \%$ \\
\hline & \multirow{5}{*}{ Interest rates } & \multirow{5}{*}{$73.00 \%$} & Irrelevant & $0.00 \%$ \\
\hline & & & Little relevant & $20.00 \%$ \\
\hline & & & Indifferent & $20.00 \%$ \\
\hline & & & Relevant & $35.00 \%$ \\
\hline & & & Very relevant & $25.00 \%$ \\
\hline \multirow{15}{*}{ Profile } & \multirow{5}{*}{$\begin{array}{l}\text { Environmental } \\
\text { concern }\end{array}$} & \multirow{5}{*}{$58.00 \%$} & Irrelevant & $5.00 \%$ \\
\hline & & & Little relevant & $35.00 \%$ \\
\hline & & & Indifferent & $25.00 \%$ \\
\hline & & & Relevant & $35.00 \%$ \\
\hline & & & Very relevant & $0.00 \%$ \\
\hline & \multirow{5}{*}{$\begin{array}{l}\text { Consumer } \\
\text { knowledge }\end{array}$} & \multirow{5}{*}{$60.00 \%$} & Irrelevant & $15.00 \%$ \\
\hline & & & Little relevant & $15.00 \%$ \\
\hline & & & Indifferent & $30.00 \%$ \\
\hline & & & Relevant & $35.00 \%$ \\
\hline & & & Very relevant & $5.00 \%$ \\
\hline & \multirow{5}{*}{$\begin{array}{l}\text { Influence of other } \\
\text { agents }\end{array}$} & \multirow{5}{*}{$74.00 \%$} & Irrelevant & $10.00 \%$ \\
\hline & & & Little relevant & $0.00 \%$ \\
\hline & & & Indifferent & $25.00 \%$ \\
\hline & & & Relevant & $40.00 \%$ \\
\hline & & & Very relevant & $25.00 \%$ \\
\hline \multirow{5}{*}{ Life standard } & \multirow{5}{*}{ Lifestyle } & \multirow{5}{*}{$73.00 \%$} & Irrelevant & $5.00 \%$ \\
\hline & & & Little relevant & $15.00 \%$ \\
\hline & & & Indifferent & $5.00 \%$ \\
\hline & & & Relevant & $60.00 \%$ \\
\hline & & & Very relevant & $15.00 \%$ \\
\hline
\end{tabular}


Table 3. Cont.

\begin{tabular}{|c|c|c|c|c|}
\hline Topic & Indicator & $\begin{array}{l}\text { Relevance of } \\
\text { Indicator }\end{array}$ & Answer Options & $\begin{array}{c}\text { Percentage of } \\
\text { Answers }\end{array}$ \\
\hline & \multirow{5}{*}{ Residential } & \multirow{5}{*}{$71.00 \%$} & Irrelevant & $5.00 \%$ \\
\hline & & & Little relevant & $10.00 \%$ \\
\hline & & & Indifferent & $25.00 \%$ \\
\hline & & & Relevant & $45.00 \%$ \\
\hline & & & Very relevant & $15.00 \%$ \\
\hline & \multirow{5}{*}{ Housing value } & \multirow{5}{*}{$73.00 \%$} & Irrelevant & $0.00 \%$ \\
\hline & & & Little relevant & $15.00 \%$ \\
\hline & & & Indifferent & $10.00 \%$ \\
\hline & & & Relevant & $70.00 \%$ \\
\hline & & & Very relevant & $5.00 \%$ \\
\hline
\end{tabular}

From the classification of indicators, the main objective of the first part of the interviews is to measure the representation of each one of them to predict the adoption of photovoltaic technology from the perspective of electricity distributors to assist in the development of more accurate accession prediction methods. In the second part, the interviewees were allowed to express their opinions according to their personal and professional experiences, seeking to understand their views on photovoltaic diffusion. Furthermore, verifying if the indicators identified in the literature were sufficient for electricity distributors to make the forecast or if it was necessary to add more elements to the study.

\subsubsection{Description of the Results of the Opinion Questions}

Initially, respondents were asked about their opinion on photovoltaic diffusion, as well as its technical, political, and economic implications. A5 said that he is "favorable to photovoltaic diffusion". At the same time, I2, M2, and M3 affirmed that the dissemination of technology is essential for the growth and diversification of the energy matrix. However, still it depends on government incentives and cost reductions. I3 ratified the information by saying that "diffusion is still embryonic" and A2 added that "photovoltaic expansion represents a way of meeting the growing demand with environmentally sustainable characteristics, although it presents challenges for the electricity sector". The interviewee R1 pointed out that "it is a current and relevant theme and it is expanding rapidly", however more public policies should encourage its use. This statement was corroborated by $\mathrm{C} 2$, who emphasized the importance of diffusion and said that the bodies and companies that structure the electricity sector "could not follow this process at the same speed as the development of these energy sources occurred in Brazil". Additionally, I1 referred to regulators and pointed out that photovoltaic diffusion should be encouraged by industry agencies. At the same time, C1 stated that photovoltaic technology "is on the rise and is beginning to be spread among customers."

A1 underlined about consumer rights and said that "individual choice to adopt a system should be allowed and respected as long as it does not harm other customers." A4 stated that "the population should be made aware of the cost-benefits of technology." Meanwhile, A3 and R2 suggested that in Brazil there is a need for suppliers to disclose information to people since there is a reduced number of suppliers, campaigns, and government incentives for adopting photovoltaic energy. Even though G1 does not have high technical knowledge about photovoltaic technology, he said that this form of generation is a clean technology and that "the main factor for its use is the cost-benefit that would be generated". R4 focused his opinion on professionals from the photovoltaic sector, mentioning that the technology is "not widespread in the market, and there are few skilled professionals". E1 highlighted the economic aspects of technology and pointed out that "the continuous cost reduction 
of photovoltaic systems combined with the high costs of commercial electricity are important elements for its dissemination in Brazil."

C3 stressed the vision of power utilities, stating that "the possibility of transferring power generation directly to the customers was probably the government motivation to encourage photovoltaic installation" and pointed out that photovoltaic diffusion "avoids large investments in the extension of transmission lines and substations." Moreover, he stated that "the incentive for photovoltaic adoption has caused a clutter among clients who generate their energy and all customers who are not installing solar generation are paying indirectly on their bills the value of investments for improvements to microgeneration connections". With a more systemic view, R3 argued that there would be "implications for the energy market as concessionaires will become more and more providers of energy transport services than energy traders. So, there is a significant impact on the electricity sector of the business model, which has an uncertain future." The interviewee also points out that "the customer starts to see himself as an energy producer and not just as a consumer of the service", which leads him to want a more significant space for decision.

The interviewees were also asked about additional information to predict consumer acquisition, as well as whether the indicators created were sufficient for this task. The respondents A5, C1, G1, I1 M2, and R2 argued that all aspects were addressed, emphasizing the benefits and the return of the investment for the clients. A2 suggested paying more attention to pricing, as "the higher the tariffs, the more favored the distributed generation facilities are" corroborating with I2's opinion, who stresses the importance of energy costs. In this regard, A4 emphasized that "the decision is directly linked to cost-benefit" and emphasized the importance of an individual knowing distributed generation legislation. From another perspective, C2 quoted that "it would be interesting to observe the people's desire to deploy power generation systems with power exceeding their consumption to share the surplus energy with others." C3 noted that "for clients the initial step is restructuring the energy use, focusing on factors related to the consumption optimization, and the second step may be the installation of generation using alternative energy", while M3 stated that "the system efficiency is very important to measure generation and optimize consumption."

To bring new comparisons, R1 proposed comparing adherence potentials in urban and rural areas, as well as small and large cities. M1 highlighted the importance of measuring the solar radiation of the place, while E1 declared that "it is necessary a consistent recovery of production activities in Brazil to reduce unemployment and improve the purchasing power of potential adherents to the photovoltaic technology." R4 took a closer look at the influence of integrators in consumer decision-making, arguing that "it would be interesting to measure the technical capacity of companies that implement photovoltaic projects." However, A3 suggested measuring "the daily sales per the supplier of each integrator, so that it can be understood in which regions the demand is growing, for which social classes, and which factors influence this growth." R3 affirmed that the variables raised are adequate to measure the decision factors for small business clients with the main factors: The return of investment, safety, and reliability of technology, and the influence exerted by other people who installed photovoltaic systems. Furthermore, according to R3, two relevant factors were not listed in the survey. One of them is the local suppliers, which increases the investment security, and the second is the local competition, since "several suppliers offer a guarantee that the price is according to the market prices and is not overestimated, which also guarantees the quality of the purchase".

\section{Analysis of Results}

This topic analyzes the results obtained, considering the interviews with professionals in the energy sector and the information collected in the academic literature. For this, the indicators and topics to predict the adoption of photovoltaic technology are grouped in dimensions of economic viability and behavioral viability, according to the framework presented in Figure 2. The dimension economic viability covers the issues of the photovoltaic system and cost-benefit, while the profile and life standard form the behavioral viability dimension. This division into two dimensions is 
essential so that it is possible to understand the relationship of topics and indicators with the opinion of the interviewees and the studies already developed in the literature on forecasting adoption to photovoltaic technology.

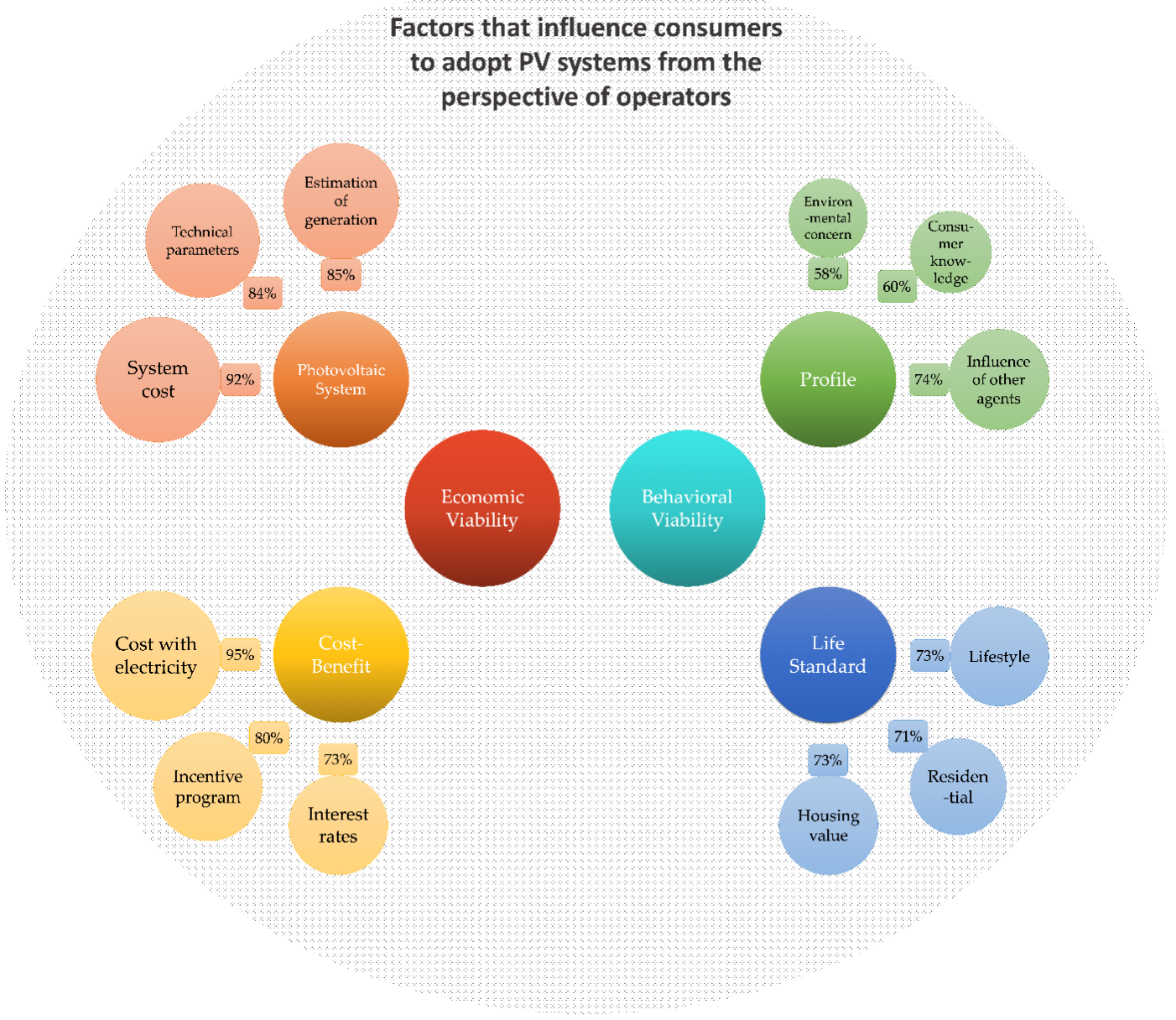

Figure 2. Factors to consumers' adoption of photovoltaic (PV) systems from the perspective of operators.

\subsection{The Dimension of Economic Viability}

This topic describes the aspects related to economic viability that influence the consumer's decision through the financial benefit of purchasing a photovoltaic system. Thus, to predict economic viability, it is necessary to understand aspects related to the topics of the photovoltaic system and cost-benefit, as shown in Table 4.

Table 4. Hierarchical order of economic viability dimension indicators by relevance index.

\begin{tabular}{ccc}
\hline Topic & Indicator & Relevance Index \\
\hline Cost-benefit & Cost with electricity & $95.00 \%$ \\
\hline Photovoltaic system & System cost & $92.00 \%$ \\
\hline Photovoltaic system & Estimation of generation & $85.00 \%$ \\
\hline Photovoltaic system & Technical parameters & $84.00 \%$ \\
\hline Cost-benefit & Incentive program & $80.00 \%$ \\
\hline Cost-benefit & Interest rates & $73.00 \%$ \\
\hline
\end{tabular}


The leading indicator of the economic viability dimension was the cost of electricity, which has political and economic importance and involves fees, energy consumption by the consumer unit, and the electricity tariff, which is defined by the electricity sector regulator with the concessionaire through resolutions, ordinances, and laws. This indicator had the highest relevance (95\%) for the interviewees since electricity consumption and tariff policies are determining factors in the country's socio-economic development [91]. The increase in electricity tariffs, mainly noticed in groups B1 (residential) and B3 (commercial) of the low-voltage distribution network [92], can act as an incentive for the adoption of photovoltaic systems [93,94], which can lead the consumer to think about independence from the energy distributor [95]. Respondents agreed with this reasoning, stating that the higher the electricity tariff, the more favored the installation of distributed generation systems is, and the high costs of electric energy are essential drivers for the dissemination of photovoltaic technology in Brazil.

According to experts, the reason that the electricity cost indicator is considered the main parameter to be measured is due to the high electricity costs in Brazil. High taxes mainly cause this phenomenon levied in the country [96], unlike other countries like Switzerland, where low electricity prices and low self-consumption rates are among the economic factors that can limit the penetration of photovoltaic solar energy [46]. The 63 distribution network operators in Brazil are natural monopolies in their supply areas. Therefore, electricity rates are determined by the regulatory agency ANEEL. These tariffs are divided into tariff groups, which represent the different types of consumers, consisting of an essential indicator for electricity distributors since the variation in electricity tariffs related to different kinds of consumers influences the economic analysis of investment in distributed photovoltaic generation projects [97].

Another element of significant importance (92\%) is the system cost, which represents the cost of technology, and this is one of the most relevant motivators for adhering to photovoltaic technology. The representativeness of this indicator is confirmed by the authors of [56], who pointed out that an incremental reduction of $17.6 \%$ in investment costs in distributed photovoltaic generation leads to an increase of $26.1 \%$ in the total number of adopters. The initial cost of a photovoltaic system comprises high values for photovoltaic modules, circuit breakers, and cables, as well as the labor costs, which is a crucial component of the total installation cost [98]. According to Ref. [99], a lower retail price for photovoltaic systems may increase the number of potential investors to buy them. It is corroborated by Ref. [59], who confirms that the expenses associated with photovoltaic generation have been significantly reduced, and this will remain the same in the coming years, increasing competitiveness. The author of Ref. [100] states that the costs of implementing photovoltaic solutions in Brazil tend to decrease each year in the range of $3.3 \%$ to $6.5 \%$ by 2030 .

Respondents highlighted that the continuous reduction in costs of photovoltaic systems is an essential factor for the dissemination of this technology in Brazil. On the other hand, they pointed out that, even though the photovoltaic generation continues to grow, the costs are still high, leading to greater adoption by consumers with greater buying power. Political interventions in Europe and North America, aiming at the fulfillment of their respective $\mathrm{CO}_{2}$ reduction targets, appear as the first causal element of the reduction observed in the leveled costs of photovoltaic systems [101]. In this context, distribution system operators need to make a more considerable effort to monitor public incentives for the acquisition of photovoltaic systems. Also, they need to observe the number of integrators in their region of operation, since the increase in options of integrating companies in the area reduces operating costs and increases competitiveness [102]. It is also noteworthy that regions with greater competitiveness tend to have more available costs for consumers [103].

In addition to the system cost, the topic of the photovoltaic system is structured into two other indicators that represent the generation estimate and technical parameters, which constitute the technical part of photovoltaic systems. The authors of Ref. [104] state that the generation capacity is directly related to the estimated generation, which includes the location, climatic conditions, position, and solar irradiation. It is also associated with technical parameters, which consist of qualified workers, equipment, efficiency, durability, power, positioning, shading, and inclination of photovoltaic 
modules [105]. The respondents pointed out that system efficiency is one of the most determining elements for measuring technical parameters with a relevance of $84 \%$. The authors of [106] corroborate that, stating that although the photovoltaic modules have an extended life cycle, the energy of the system can be significantly influenced by degradation phenomena that can reduce the efficiency of the system.

Photovoltaic adoption requires high technical standards [87]. Although Brazil stands out in terms of solar radiation [9], the largest markets for photovoltaic systems are China, Germany, Italy, and the United States, which have greater technical maturity [88]. The quality of photovoltaic systems is fundamental for the adoption of this technology [61] because its efficiency is directly linked to the economy that the individual will have by adopting it since more efficient equipment ensures a higher generation of electric power [107]. The estimated production has high measurement importance of $(85 \%)$ because, depending on the available irradiation, the return on investment can take a long time, making the use of photovoltaic energy a non-financially viable option [98]. The information about the location of the consumer units, present in the electricity distributors' databases, can be used to measure the indicators of generation estimate and technical parameters. The location of a consumer unit can indicate the solar incidence [56], the solar position [108], and the amount of shading since the photovoltaic modules work best when the lighting is uniform across the light-sensitive surface [109].

Other factors that can be monitored by electricity distributors are the knowledge of advanced technologies and the workforce of integrators, which can result in problems associated with the implementation and maintenance of renewable energy projects [110] and cause significant impacts on the distribution network. The respondents also mentioned the issue of technical knowledge and the experience of integrators. They highlighted that integrators need specialized training, stating that the technology is still incipient in the market, and there are few qualified professionals. Furthermore, they highlight technical issues related to the distribution grid and state that the massive photovoltaic penetration implies possible problems and the need for investments and modernization of the electricity grids. Among the main technical factors that affect the distribution network, it can be highlighted the peak load shaving, voltage profile, system losses, reliability, power quality, line loading, stability, and protection [111]. These aspects can cause difficulties and resistance by the distributors regarding photovoltaic diffusion due to the resulting economic and financial impacts.

The incentive program indicator, as well as the expenses with electricity, are part of the cost-benefit topic and also has a high relevance $(80 \%)$. This variable covers public policies, government incentives, and discounts by integrators to encourage adherence to photovoltaic technology, corroborating with Ref. [112], who emphasizes the importance of public policies for the diffusion of distributed photovoltaic generation. Respondents pointed out that one of the main motivations of the government to encourage consumers to adhere to photovoltaic technology was to transfer the responsibility of generation directly to consumers. Furthermore, they pointed out that government actions should be accompanied by education and awareness campaigns by all agents and that the choice to adopt a photovoltaic system is inherent to the individual and must be respected by the government, which must formulate policies that contribute systemically to the sector. In this sense, electricity distributors must adhere to public policies and tax incentives in their regions of operation. One of them is the exemption from the Tax on the Circulation of Goods and Services (ICMS), a politico-economic aspect that can increase adoption of photovoltaic technology [61].

The cost-benefit topic is still structured by the interest rate indicator, which represents the credit options that the market has to finance the purchase of photovoltaic systems, given that the Brazilian population is heavily dependent on bank financing for the acquisition of photovoltaic systems [61]. The interest rate indicator has a relevance of $73 \%$, the lowest within the dimension of economic viability, but is of great importance for forecasting the adoption, as consumer access to finance is a good indicator of adherence that should be monitored by distribution system operators. When asked about photovoltaic diffusion, respondents argued that incentive economic policies are relevant and that taxes are a consequence of public policy and the economy of the country. Also, they stated that 
greater legal security and a continued economic recovery are necessary for the country, as these issues may generate instability in the scenario of diffusion of photovoltaic technology, causing difficulties in measuring this type of information in the long term.

In the current scenario, Germany, Italy, Japan, Spain, the USA, China, France, Belgium, Czech Republic, and Australia are the world's top 10 producers of solar energy. Like Brazil, they depend mainly on their policies, with liquid measurement instruments and green certification, low-interest bank loans, renewable portfolio standards, and national renewable energy targets [113]. Regarding the measurement by electricity utilities, the separation of consumers by tariff groups seems to be a viable alternative, since each group represents an economic class and has access to different financing mechanisms. Thus, groups that have easy access to obtain financing have advantages and a greater tendency to join photovoltaic systems.

The return on investment and the financial capacity to buy a photovoltaic system are the key decision-makers for consumers to adopt this technology. The authors of [67] affirm that the economic aspect is more critical for the adopters of the photovoltaic system because when installing it, the customer is concerned about the financial benefit. Respondents stated that there is a need for greater clarification from the population regarding the costs and benefits of photovoltaic systems, and one of the most significant aspects for consumers' acquisition is the cost-benefit, reiterating that the economic viability directly influences the adoption of photovoltaic technology. The authors of [92] point out that without the economic viability of photovoltaic systems in Brazil, only a small number of companies and private households will invest in these systems due to the lack of profitability.

In Greece, unlike the Brazilian reality, consumers can adopt photovoltaic systems despite the lack of direct economic incentives [49]. Thus, it is safe to say that, to predict the adoption of photovoltaic technology in Brazil and countries with similar characteristics, the indices that measure economic viability for the customer are significant. Regardless of the methods used, understanding how people behave economically and the variables that involve their financial return ensures the best estimate to predict and understand photovoltaic diffusion.

It is possible to observe that the most relevant indicators, such as electricity cost (tariffs and consumption), are parameters that can be monitored internally by the distribution system operators. The indicator estimation of generation (location, roof area, solar incidence, and solar position) can be measured through the union of the distributor's database with georeferencing databases, facilitating and substantially reducing the costs for the development of forecasting models. Other economic issues, such as the cost of photovoltaic systems offered in the region of electricity concessionaires, are also highly relevant, reaffirming the importance of monitoring the costs to consumers and integrators since these parameters have a strong influence on the migration to photovoltaic technology.

\subsection{The Dimension of Behavioral Viability}

This topic describes the aspects related to behavioral viability that influence consumer decision making through personal benefit and financial capacity to acquire a photovoltaic system. The act of buying a photovoltaic system is a decision, where potential users often invest substantial time and consideration before deciding [95]. It is necessary to understand the aspects related to the topics of consumer's profile and life standard to predict behavioral viability, as well as the variables that compose them, which are presented in Table 5. 
Table 5. Hierarchical order of behavioral viability dimension indicators according to relevance index.

\begin{tabular}{ccc}
\hline Topic & Indicator & Relevance Index \\
\hline Profile & Influence of other agents & $74.00 \%$ \\
\hline Life standard & Lifestyle & $73.00 \%$ \\
\hline Life standard & Housing value & $73.00 \%$ \\
\hline Life standard & Residential & $71.00 \%$ \\
\hline Profile & Consumer knowledge & $60.00 \%$ \\
\hline Profile & Environmental concern & $58.00 \%$ \\
\hline
\end{tabular}

The influence indicator of other agents, which is part of the profile topic, occupies the most important aspect $(74 \%)$ within the behavioral viability dimension. This result is consistent with the studies by Ref. [78], Ref. [79], and Ref. [62], who highlight interpersonal communication and adaptation to the norms as reasons for this relationship. The authors of Refs. [114-116] emphasize that the acquisition of a photovoltaic system by other individuals is a motivating factor because it helps to overcome the uncertainties associated with the adoption of photovoltaic panels. Moreover, it is observed that social incentives can generate drastic changes in clients' behavior [117]. The interviewee's opinion corroborates the literature, arguing that one of the most critical issues for the adherence corresponds to the influence the people who already have this technology have on other people. Ref. [67] mentions that with the increase in adopters of the photovoltaic system, it will consequently influence more people to access this technology.

When comparing photovoltaic diffusion in different countries, it is noticeable that developed countries like Japan and Canada are considered models for developing countries like China and India [118]. Since Brazil is a developing country, its interaction and learning regarding photovoltaic technology are likely the results of the influence of other countries. This relationship is vital for Brazilian electricity distributors since solutions already established in developed countries can have a connection and impact in the Brazilian scenario. However, for distribution system operators to monitor photovoltaic diffusion, the use of internal information from consumer units already opting for photovoltaic systems is useful in forecasting adoption. It is because the electricity distributor can map its consumer units and indicate which consumers are affected by this type of influence, taking into account their operating characteristics [119].

The life standard stands out, dealing with information such as the residence value, where people live, their salary, or how they live. This information helps to identify the customer's financial capacity to acquire and purchase photovoltaic technology. Among the indicators that form this topic, lifestyle stands out, which has the relevance of $73 \%$ and involves the income of consumers and their habits as stated by Ref. [67], and it should be considered customer income when it is desired to predict adherence to photovoltaic technology. Nevertheless, social categories and lifestyles and a variety of elements may be associated with an individual's decision to invest in a photovoltaic system [56]. The acquisition decisions are often linked to specific human characteristics such as gender, education, or income [74], which matches the opinion of respondents. They stressed that the costs of photovoltaic systems are still high, leading to more significant acquisition by people with more financial resources. It is noteworthy that when it comes to lifestyle, some information should be evaluated, such as consumer behavior, places where the individual goes to, and travel. Thus, considering the amount of data that makes up this variable, it is difficult to obtain a standard or accurate measurement.

The use of other external databases to monitor the income and habits of consumers can be included in the planning of distribution operators to structure the forecasting models with a higher assertiveness based on these indicators [51]. However, certain internal information present in the electricity utility databases can be relevant to measure the financial capacity of consumers, such as the number of consumer units linked to each holder consumer to know their purchasing power. The load curve is 
also relevant and can indicate how electricity is consumed in the consumer unit, characterizing an indication of consumers' lifestyle [104].

Another factor that reflects on the consumers' purchasing power is the value of housing, which indicates the ability to pay for technology [86] through the economic value of their residence [81]. In this case, information such as address $[56,86]$, which indicates if the individual lives in a good neighborhood, the built area [85], and the amount he pays for tax are considered as indicators. The respondents viewed the value of this index as a way to measure the financial capacity of customers, giving it a $73 \%$ relevance level. They argued that the customer purchasing power influences adoption. Thereby, it is noted that the value of housing should not be overlooked when seeking to predict consumer acquisition.

The residential indicator is structured through the socioeconomic information that involves both the economic and social aspects, encompassing data such as the number of residents, number of cars, and other data that can assist in predicting the people uptake to the photovoltaic technology. According to Ref. [74], those living in rented houses are extremely unlikely to install photovoltaic systems. The authors of [81] mention that residential data reflect the consumer socioeconomic scenario. However, as Ref. [88] says, these data individually do not become representative for the adoption, as aspects of cognition, social position, and communities of like-minded individuals seem to explain the variability in adoption intentions rather than standardized socioeconomic variables.

The characteristics of consumers can vary from one country to another, presenting different socioeconomic profiles and consumption behaviors. The authors of [120] highlight these differences in socioeconomic and consumption patterns when analyzing disparities in energy efficiency in a city in the USA. This country has a less renewable matrix than Brazil. The respondents also had this perception and saw the importance of this element, giving it the relevance of $71 \%$. It indicates that an effort should be made to measure and consider it whenever it is possible. The internal attributes of electricity distributors that can structure this topic are the required power and the load profile of the consumer unit since this information can indicate how consumers use electricity. It can mean the purchasing power of consumers linked to the consumer unit.

Customer knowledge is another element that integrates the profile topic, but unlike the influence of other agents, it presented lower representativeness in the degree of relevance $(60 \%)$. For the respondents, prior knowledge of technology by the customer has representativeness for the prediction of adherence to photovoltaic technology. Still, if it is not possible to measure it, perhaps this would not significantly change the result of the forecast. The literature confirms that adopters need knowledge of a product to motivate themselves to seek more information about the subject [121]. The interviewees did not specifically comment on consumer knowledge of photovoltaic technology. Still, they reported that the customer needs to be better aware of this technology and need to be created better ways to disseminate this information. The lack of knowledge is one of the main barriers to the acquisition of photovoltaic systems $[95,116]$, and it is important to note that people with higher levels of education are the ones who decide to buy this system [99]. Therefore, it is plausible to relate the diffusion and photovoltaic maturity of countries like the USA [47], Germany, and Canada [55] to a high educational level. In contrast, Brazil and other developing countries have a lower educational level [122]. For the distribution system operators to be able to measure this topic, an alternative is to add the education of the holder consumer to the internal record of the electricity distributor

The last aspect of the profile topic is the indicator of environmental care, which indicates the customer level of concern with the environment. The authors of [123] note that environmentally conscious people are more likely to pay higher prices and will be more aware of carbon emissions into the atmosphere. The authors of [124] consider that environmental values have a positive impact on the ecological lifestyle and intentions of the solar energy system. However, in Brazil, domestic and business cultures are not sufficiently concerned about the environment and sustainable development [125]. It is possible to observe this point in the interviewees' classification, regarding the relevance of the indicator (58\%), which can be dispensed when it is not possible to measure it. As Brazil is a developing 
country, it may tend materialism, as well as what happens in Lithuania [126], which can reduce environmental concerns.

It can be concluded that the profile topic provides a degree of importance that should not be ignored, despite being the least significant when the objective is to predict consumer adoption to photovoltaic technology. When possible, it should be measured. The aspects related to the profile refer to the decisions and personal influences of individuals, and each person has different influences that must be considered. Although they have a certain level of impact on the forecasting process, the dimension of behavioral variability indicates the specialists that have less relevance than those of the economic viability. The indicators with commercial bias stand out as the most representative when it is intended to predict consumer adoption. These results are representative of Brazil and other countries with similar realities, while developed countries in North America, Europe, and Asia may have different views on the elements analyzed.

\section{Conclusions}

In this article, most important factors and indicators to predict consumer adoption to photovoltaic technology were investigated, considering the perspective of distribution system operators, which were later analyzed and evaluated by experts from the electricity sector. The results of the analysis of these indicators show that photovoltaic agents are optimistic about the prospects for the diffusion and adoption of photovoltaic technology, especially with the reduction of costs, the increased financial attractiveness of such projects, and the potential contribution for the electricity sector. Electricity specialists are also optimistic, but more cautiously, as they view potential regulatory and economic problems, especially regarding the sustainability of distribution.

Technical and economic indicators related to photovoltaic systems are seen as crucial success factors linked to the economic viability of the consumer. They can be measured by distributors to some extent through the use of proprietary data already existing in electricity distribution companies, enabling the reduction of costs in the accomplishment of the adoption forecast. For a more accurate result, the combination of these parameters with the consumer's values, and ability to invest capital, represented by the behavioral viability indicators, can yield better results when assisting the electricity distributors in their decision making. It is also worth noting that the scenarios vary between different countries due to the personal characteristic of photovoltaic adoption, mainly due to the dependence on public policies. Thus, although some factors are compatible for use in different scenarios, the distribution system operators must stick to their reality, thus ensuring greater assertiveness in the measurement of photovoltaic adoption in their area of operation.

This research contributes to the theory by determining factors and indicators for predicting consumer accession to photovoltaic technology from the perspective of electricity distributors and assessing its relevance. Moreover, it presents the view from agents and specialists involved in the electricity and photovoltaic sector, serving as an assessment of the current scenario of photovoltaic technology in Brazil. It is noteworthy that other studies have already been carried out in the country, as well as in developing economies that have raised aspects that contribute and others that reduce the consumers' acquisition of this system. However, this research brings a new perspective by surveying the most relevant factors and indicators to be used in forecasting models, i.e., it takes into account the reasons for people to adhere to photovoltaic technology, which is necessary to predict this accession, and which variables need to be present in the forecasting models so that electricity distributors sustainably anticipate consumers and plan.

The results also showed that Brazilian experts consider that economic issues are more important for consumers to make decisions regarding the adoption of photovoltaic systems. It is possible to observe that the influences of other agents are relevant in the Brazilian reality, but economic issues related mainly to the investment in photovoltaic systems and electricity costs stand out from the perspective of the interviewees. It may demonstrate a specific characteristic of Brazil or of developing countries, which have lower educational levels, less concern for the environment, and less purchasing 
power. This result indicates the high relevance attributed to economic issues by the experts interviewed, since the financial aspects have a more significant impact on the reality of the Brazilian population, in contrast to developed countries, which are more concerned with behavioral issues.

Regarding political implications, it is observed that predicting the adoption of photovoltaic panels by consumers is extremely important for the planning of studies about the electric system since the decision to access this type of system is up to each individual and not the centralized government decision from the government. The unique characteristics of each individual making this decision have implications for the entire electricity sector. Thus, it is crucial to assist the regulatory agencies and government entities in developing better public policies aiming at the sustainability of the sector. Additionally, the study contributes in a practical way to the distribution companies, which are suffering impacts caused by photovoltaic diffusion according to the opinion of the interviewees. Thereby, with the possibility of forecasting the adherence of their consumers, power concessionaries can reduce their impacts and also improve their business models. It is noted that new opportunities for cooperation between governments, stakeholders, and the general public are increasingly present, and any insight gained in such fields is likely to motivate regional planners, entrepreneurs, and national authorities to engage in the energy transition process.

For future research, it is possible to highlight a better understanding of the factors and reasons that influence the prediction of adoption to photovoltaic technology. Also, its effects and the development of forecasting models for the distribution sector can be studied, since there is still much to be explored for the development of this sector. Besides that, these indicators can be analyzed and evaluated through interviews with customers who have photovoltaic systems or are potential buyers of it. It is noteworthy that this study was conducted in Brazil. Still, it is believed that many of the findings are relevant to underdeveloped countries or regions of developed countries, where the presence of solar panels is still incipient.

Author Contributions: Conceptualization, F.M.d.N., J.C.M.S., F.d.S.S., and T.B.G.; methodology, F.M.d.N., J.C.M.S., F.d.S.S., and T.B.G.; validation, F.M.d.N., and J.C.M.S.; formal analysis, F.M.d.N., F.d.S.S., and T.B.G.; investigation, F.M.d.N.; data curation, F.M.d.N.; writing—original draft preparation, F.M.d.N.; writing—review and editing, J.C.M.S., F.d.S.S., T.B.G., J.R.P., and C.R.; supervision, J.C.M.S., J.R.P. and C.R.; project administration, J.C.M.S. All authors have read and agreed to the published version of the manuscript.

Funding: This research was funded by the Conselho Nacional de Desenvolvimento Científico e Tecnológico [grant numbers 311926/2017-7, 142448/2018-4, 310594/2017-0 and 465640/2014-1], Coordenação de Aperfeiçoamento de Pessoal de Nível Superior [grant numbers 1773252/2018, 1845395/2019 and 23038.000776/2017-54] and Fundação de Amparo à Pesquisa do Estado do Rio Grande do Sul [grant number 17/2551-0000517-1].

Acknowledgments: The authors thank to Conselho Nacional de Desenvolvimento Científico e Tecnológico (CNPq), Coordenação de Aperfeiçoamento de Pessoal de Nível Superior (CAPES), Fundação de Amparo à Pesquisa do Estado do Rio Grande do Sul (FAPERGS) and Institutos Nacionais de Ciência e Tecnologia-Geração Distribuída (INCT-GD) for supporting this research.

Conflicts of Interest: The authors declare no conflict of interest. The funders had no role in the design of the study; in the collection, analyses, or interpretation of data; in the writing of the manuscript, or in the decision to publish the results.

Appendix A. - Interview for Measuring the Relevance of Indicators Associated with the Forecasting of Photovoltaic Technology

\section{Appendix A.1. Photovoltaic System}

Appendix A.1.1. System Costs (Investment and Maintenance, etc...)

What is the level of relevance that the costs of the system represent for the decision of consumer adoption to the distributed photovoltaic generation?
(a) Irrelevant
(b) Little relevant
(c) Indifferent 
(d) Relevant

(e) Very Relevant

Appendix A.1.2. Technical Parameters (Quantity, Power, Efficiency, Lifetime, etc...)

What is the level of relevance that the technical parameters represent for the decision of consumer adoption to distributed photovoltaic generation?
(a) Irrelevant
(b) Little relevant
(c) Indifferent
(d) Relevant
(e) Very Relevant

Appendix A.1.3. Estimated Generation (Solar Irradiation, Roof Area, etc...)

What is the level of relevance that the on-site generation capacity estimate represents for the consumer's decision to join photovoltaic distributed generation?
(a) Irrelevant
(b) Little relevant
(c) Indifferent
(d) Relevant
(e) Very Relevant

Appendix A.2. Cost-Benefit

Appendix A.2.1. Cost with Electricity

What is the level of relevance that the cost of electricity represents for the decision of consumer adoption to distributed photovoltaic generation?
(a) Irrelevant
(b) Little relevant
(c) Indifferent
(d) Relevant
(e) Very Relevant

Appendix A.2.2. Incentive Programs

What is the level of relevance that government incentive programs or tax discounts represent for consumers' decision to join photovoltaic distributed generation?
(a) Irrelevant
(b) Little relevant
(c) Indifferent
(d) Relevant
(e) Very Relevant

Appendix A.2.3. Interest Rates

What is the level of relevance that interest rates (bank, consortium, among others) represent for the decision of consumer adoption to distributed photovoltaic generation?
(a) Irrelevant
(b) Little relevant
(c) Indifferent
(d) Relevant
(e) Very Relevant 
Appendix A.3. Profile

Appendix A.3.1. Environmental Concern

What is the level of relevance that the environmental concern represents for the decision of consumer adoption to the distributed photovoltaic generation?
(a) Irrelevant
(b) Little relevant
(c) Indifferent
(d) Relevant
(e) Very Relevant

Appendix A.3.2. Knowledge Level

What is the level of relevance that knowledge about photovoltaic technology represents for the decision of consumer adoption to distributed photovoltaic generation?
(a) Irrelevant
(b) Little relevant
(c) Indifferent
(d) Relevant
(e) Very Relevant

Appendix A.3.3. Agent Interactions

What is the level of relevance that other consumers with photovoltaic systems can represent in the decision of consumer adoption to distributed photovoltaic generation?
(a) Irrelevant
(b) Little relevant
(c) Indifferent
(d) Relevant
(e) Very Relevant

Appendix A.4. Life Standard

Appendix A.4.1. Lifestyle

What is the level of relevance that consumers' lifestyles can play in deciding whether or not the consumer will adhere to photovoltaic distributed generation?
(a) Irrelevant
(b) Little relevant
(c) Indifferent
(d) Relevant
(e) Very Relevant

\section{Appendix A.4.2. Residential Data}

What is the level of relevance that the number of residents and other residential data (appliances, number of cars, among others) can exert for the decision of consumer adoption to photovoltaic distributed generation?
(a) Irrelevant
(b) Little relevant
(c) Indifferent
(d) Relevant
(e) Very Relevant 
Appendix A.4.3. Housing Value

What is the level of relevance that the value (financial and local) of housing can exert for the decision of consumer adoption to photovoltaic distributed generation?
(a) Irrelevant
(b) Little relevant
(c) Indifferent
(d) Relevant
(e) Very Relevant

\section{Appendix A.5. Discursive Questions:}

(1) What is your opinion about photovoltaic diffusion (technical, political and economic implications, among others)?

(2) What supplemental information would you use to monitor and predict the consumer's decision to purchase photovoltaic systems? Why?

\section{References}

1. Jasiński, T. Modeling electricity consumption using nighttime light images and artificial neural networks. Energy 2019, 179, 831-842. [CrossRef]

2. Hou, J.P.; Li, R.; Wang, Q.; Yu, H.Y.; Zhang, Z.J.; Chen, Q.Y.; Ma, H.; Wu, X.M.; Li, X.W.; Zhang, Z.F. Three principles for preparing $\mathrm{Al}$ wire with high strength and high electrical conductivity. J. Mater. Sci. Technol. 2019, 35, 742-751. [CrossRef]

3. Bórawski, P.; Bełdycka-Bórawska, A.; Szymańska, E.J.; Jankowski, K.J.; Dubis, B.; Dunn, J.W. Development of renewable energy sources market and biofuels in The European Union. J. Clean. Prod. 2019, 228, 467-484. [CrossRef]

4. Aydin, M. Renewable and non-renewable electricity consumption-economic growth nexus: Evidence from OECD countries. Renew. Energy 2019, 136, 599-606. [CrossRef]

5. Frondel, M.; Sommer, S.; Vance, C. Heterogeneity in German Residential Electricity Consumption: A quantile regression approach. Energy Policy 2019, 131, 370-379. [CrossRef]

6. Thakur, J.; Chakraborty, B. Impact of compensation mechanisms for PV generation on residential consumers and shared net metering model for developing nations: A case study of India. J. Clean. Prod. 2019, 218, 696-707. [CrossRef]

7. Cherry, C.E.; Pidgeon, N.F. Is sharing the solution? Exploring public acceptability of the sharing economy. J. Clean. Prod. 2018, 195, 939-948. [CrossRef]

8. Du, Y.; Song, B.; Duan, H.; Tsvetanov, T.G.; Wu, Y. Multi-renewable management: Interactions between wind and solar within uncertain technology ecological system. Energy Convers. Manag. 2019, 187, 232-247. [CrossRef]

9. de Azevedo Dias, C.L.; Castelo Branco, D.A.; Arouca, M.C.; Loureiro Legey, L.F. Performance estimation of photovoltaic technologies in Brazil. Renew. Energy 2017, 114, 367-375. [CrossRef]

10. Rosa, C.B.; Rediske, G.; Rigo, P.D.; Wendt, J.F.M.; Michels, L.; Siluk, J.C.M. Development of a computational tool for measuring organizational competitiveness in the photovoltaic power plants. Energies 2018, 11, 867. [CrossRef]

11. de Dantas, G.A.; de Castro, N.J.; Brandão, R.; Rosental, R.; Lafranque, A. Prospects for the Brazilian electricity sector in the 2030s: Scenarios and guidelines for its transformation. Renew. Sustain. Energy Rev. 2017, 68, 997-1007. [CrossRef]

12. Shields, P.; Rangarjan, N. A Playbook for Research Methods: Integrating Conceptual Frameworks and Project Management; New Forums Press Inc.: Stillwater, OK, USA, 2013; pp. 193-229.

13. Satchwell, A.; Mills, A.; Barbose, G. Quantifying the financial impacts of net-metered PV on utilities and ratepayers. Energy Policy 2015, 80, 133-144. [CrossRef]

14. Snook, L.R.; Grabel, M.H. Dispelling the myths of residential rate reform: Why an evolving grid requires a modern approach to residential electricity pricing. Electr. J. 2016, 29, 72-76. [CrossRef] 
15. Eid, C.; Reneses Guillén, J.; Frías Marín, P.; Hakvoort, R. The economic effect of electricity net-metering with solar PV: Consequences for network cost recovery, cross subsidies and policy objectives. Energy Policy 2014, 75, 244-254. [CrossRef]

16. Richter, M. Business model innovation for sustainable energy: How German municipal utilities invest in offshore wind energy. Int. J. Technol. Manag. 2013, 63, 24. [CrossRef]

17. Muaafa, M.; Adjali, I.; Bean, P.; Fuentes, R.; Kimbrough, S.O.; Murphy, F.H. Can adoption of rooftop solar panels trigger a utility death spiral? A tale of two U.S. cities. Energy Res. Soc. Sci. 2017, 34, 154-162. [CrossRef]

18. Johnson, E.; Beppler, R.; Blackburn, C.; Staver, B.; Brown, M.; Matisoff, D. Peak shifting and cross-class subsidization: The impacts of solar PV on changes in electricity costs. Energy Policy 2017, 106, 436-444. [CrossRef]

19. Heideier, R.; Bajay, S.V.; Jannuzzi, G.M.; Gomes, R.D.M.; Guanais, L.; Ribeiro, I.; Paccola, A. Impacts of photovoltaic distributed generation and energy efficiency measures on the electricity market of three representative Brazilian distribution utilities. Energy Sustain. Dev. 2020, 54, 60-71. [CrossRef]

20. Rigo, P.D.; Siluk, J.C.M.; Lacerda, D.P.; Rosa, C.B.; Rediske, G. Is the success of small-scale photovoltaic solar energy generation achievable in Brazil? J. Clean. Prod. 2019, 240, 118243. [CrossRef]

21. Korcaj, L.; Hahnel, U.J.J.; Spada, H. Intentions to adopt photovoltaic systems depend on homeowners' expected personal gains and behavior of peers. Renew. Energy 2015, 75, 407-415. [CrossRef]

22. Londo, M.; Matton, R.; Usmani, O.; van Klaveren, M.; Tigchelaar, C.; Brunsting, S. Alternatives for current net metering policy for solar PV in the Netherlands: A comparison of impacts on business case and purchasing behaviour of private homeowners, and on governmental costs. Renew. Energy 2020, 147, 903-915. [CrossRef]

23. Cossent, R.; Gómez, T.; Olmos, L. Large-scale integration of renewable and distributed generation of electricity in Spain: Current situation and future needs. Energy Policy 2011, 39, 8078-8087. [CrossRef]

24. Jimenez, M.; Franco, C.J.; Dyner, I. Diffusion of renewable energy technologies: The need for policy in Colombia. Energy 2016, 111, 818-829. [CrossRef]

25. Yan, X.; Ozturk, Y.; Hu, Z.; Song, Y. A review on price-driven residential demand response. Renew. Sustain. Energy Rev. 2018, 96, 411-419. [CrossRef]

26. Good, N. Using behavioural economic theory in modelling of demand response. Appl. Energy 2019, 239, 107-116. [CrossRef]

27. Ehsan, A.; Yang, Q. Optimal integration and planning of renewable distributed generation in the power distribution networks: A review of analytical techniques. Appl. Energy 2018, 210, 44-59. [CrossRef]

28. Shariatzadeh, F.; Mandal, P.; Srivastava, A.K. Demand response for sustainable energy systems: A review, application and implementation strategy. Renew. Sustain. Energy Rev. 2015, 45, 343-350. [CrossRef]

29. Niesten, E.; Alkemade, F. How is value created and captured in smart grids? A review of the literature and an analysis of pilot projects. Renew. Sustain. Energy Rev. 2016, 53, 629-638. [CrossRef]

30. Immonen, A.; Kiljander, J.; Aro, M. Consumer viewpoint on a new kind of energy market. Electr. Power Syst. Res. 2020, 180, 106153. [CrossRef]

31. Sahari, A. Electricity prices and consumers' long-term technology choices: Evidence from heating investments. Eur. Econ. Rev. 2019, 114, 19-53. [CrossRef]

32. Gambardella, C.; Pahle, M. Time-varying electricity pricing and consumer heterogeneity: Welfare and distributional effects with variable renewable supply. Energy Econ. 2018, 76, 257-273. [CrossRef]

33. Teresa Costa-Campi, M.; Davi-Arderius, D.; Trujillo-Baute, E. The economic impact of electricity losses. Energy Econ. 2018, 75, 309-322. [CrossRef]

34. Passey, R.; Watt, M.; Bruce, A.; MacGill, I. Who pays, who benefits? The financial impacts of solar photovoltaic systems and air-conditioners on Australian households. Energy Res. Soc. Sci. 2018, 39, 198-215. [CrossRef]

35. Laws, N.D.; Epps, B.P.; Peterson, S.O.; Laser, M.S.; Wanjiru, G.K. On the utility death spiral and the impact of utility rate structures on the adoption of residential solar photovoltaics and energy storage. Appl. Energy 2017, 185, 627-641. [CrossRef]

36. Castaneda, M.; Franco, C.J.; Dyner, I. Evaluating the effect of technology transformation on the electricity utility industry. Renew. Sustain. Energy Rev. 2017, 80, 341-351. [CrossRef]

37. Curtius, H.C. The adoption of building-integrated photovoltaics: Barriers and facilitators. Renew. Energy 2018, 126, 783-790. [CrossRef] 
38. Cho, Y.; Koo, Y. Investigation of the effect of secondary market on the diffusion of innovation. Technol. Forecast. Soc. Chang. 2012, 79, 1362-1371. [CrossRef]

39. Peres, R.; Muller, E.; Mahajan, V. Innovation diffusion and new product growth models: A critical review and research directions. Int. J. Res. Mark. 2010, 27, 91-106. [CrossRef]

40. Islam, T. Household level innovation diffusion model of photo-voltaic (PV) solar cells from stated preference data. Energy Policy 2014, 65, 340-350. [CrossRef]

41. Zhai, P.; Williams, E.D. Analyzing consumer acceptance of photovoltaics (PV) using fuzzy logic model. Renew. Energy 2012, 41, 350-357. [CrossRef]

42. Karakaya, E. Finite Element Method for forecasting the diffusion of photovoltaic systems: Why and how? Appl. Energy 2016, 163, 464-475. [CrossRef]

43. Lockyer, J. Diffusion of Innovations; A Division of Macmillan Publishing Co. Inc.: New York, NY, USA, 1997; Volume 17.

44. Rogers, E.M.; Singhal, A.; Quinlan, M.M. Diffusion of innovations. In An Integrated Approach to Communication Theory and Research, 3rd ed.; A division of Macmillan Publishing Co. Inc.: New York, NY, USA, 2019; ISBN 9781351358712.

45. da Pereira Silva, P.; Dantas, G.; Pereira, G.I.; Câmara, L.; De Castro, N.J. Photovoltaic distributed generation-An international review on diffusion, support policies, and electricity sector regulatory adaptation. Renew. Sustain. Energy Rev. 2019, 103, 30-39. [CrossRef]

46. Panos, E.; Margelou, S. Long-term solar photovoltaics penetration in single- And two-family houses in Switzerland. Energies 2019, 12, 2460. [CrossRef]

47. Graziano, M.; Fiaschetti, M.; Atkinson-Palombo, C. Peer effects in the adoption of solar energy technologies in the United States: An urban case study. Energy Res. Soc. Sci. 2019, 48, 75-84. [CrossRef]

48. Tidwell, J.H.; Tidwell, A.; Nelson, S. Surveying the solar power gap: Assessing the spatial distribution of emerging photovoltaic solar adoption in the State of Georgia, U.S.A. Sustainability 2018, 10, 4117. [CrossRef]

49. Martinopoulos, G.; Tsalikis, G. Diffusion and adoption of solar energy conversion systems-The case of Greece. Energy 2018, 144, 800-807. [CrossRef]

50. Tsaur, R.C.; Lin, Y.H. Exploring the consumer attitude of building-attached photovoltaic equipment using revised technology acceptance model. Sustainability 2018, 10, 4177. [CrossRef]

51. Lin, A.; Lu, M.; Sun, P. The influence of local environmental, economic and social variables on the spatial distribution of photovoltaic applications across China's urban areas. Energies 2018, 11, 1986. [CrossRef]

52. Kastner, I.; Wittenberg, I. How measurements "affect" the importance of social influences on household's photovoltaic adoption-A German case study. Sustainability 2019, 11, 5175. [CrossRef]

53. Reyes-Mercado, P.; Rajagopal, R. Adoption of renewable energy technologies in Mexico: The role of cognitive factors and innovation attributes. Int. J. Energy Sect. Manag. 2017, 11, 626-649. [CrossRef]

54. De Groote, O.; Pepermans, G.; Verboven, F. Heterogeneity in the adoption of photovoltaic systems in Flanders. Energy Econ. 2016, 59, 45-57. [CrossRef]

55. Adepetu, A.; Alyousef, A.; Keshav, S.; de Meer, H. Comparing solar photovoltaic and battery adoption in Ontario and Germany: An agent-based approach. Energy Inform. 2018, 1, 6. [CrossRef]

56. Palmer, J.; Sorda, G.; Madlener, R. Modeling the diffusion of residential photovoltaic systems in Italy: An agent-based simulation. Technol. Forecast. Soc. Chang. 2015, 99, 106-131. [CrossRef]

57. Klepacka, A.M.; Florkowski, W.J.; Meng, T. Clean, accessible, and cost-saving: Reasons for rural household investment in solar panels in Poland. Resour. Conserv. Recycl. 2018, 139, 338-350. [CrossRef]

58. dos Santos Carstens, D.D.; da Cunha, S.K. Challenges and opportunities for the growth of solar photovoltaic energy in Brazil. Energy Policy 2019, 125, 396-404. [CrossRef]

59. Ferreira, A.; Kunh, S.S.; Fagnani, K.C.; De Souza, T.A.; Tonezer, C.; Dos Santos, G.R.; Coimbra-Araújo, C.H. Economic overview of the use and production of photovoltaic solar energy in brazil. Renew. Sustain. Energy Rev. 2018, 81, 181-191. [CrossRef]

60. de Faria, H.; Trigoso, F.B.M.; Cavalcanti, J.A.M. Review of distributed generation with photovoltaic grid connected systems in Brazil: Challenges and prospects. Renew. Sustain. Energy Rev. 2017, 75, 469-475. [CrossRef]

61. Garlet, T.B.; Ribeiro, J.L.D.; de Savian, F.S.; Siluk, J.C.M. Paths and barriers to the diffusion of distributed generation of photovoltaic energy in southern Brazil. Renew. Sustain. Energy Rev. 2019, 111, 157-169. [CrossRef] 
62. Busic-Sontic, A.; Fuerst, F. Does your personality shape your reaction to your neighbours' behaviour? A spatial study of the diffusion of solar panels. Energy Build. 2018, 158, 1275-1285. [CrossRef]

63. Lee, M.; Hong, T. Hybrid agent-based modeling of rooftop solar photovoltaic adoption by integrating the geographic information system and data mining technique. Energy Convers. Manag. 2019, 183, 266-279. [CrossRef]

64. Lee, M.; Hong, T.; Jeong, K.; Kim, J. A bottom-up approach for estimating the economic potential of the rooftop solar photovoltaic system considering the spatial and temporal diversity. Appl. Energy 2018, 232, 640-656. [CrossRef]

65. Wittenberg, I.; Blöbaum, A.; Matthies, E. Environmental motivations for energy use in PV households: Proposal of a modified norm activation model for the specific context of PV households. J. Environ. Psychol. 2018, 55, 110-120. [CrossRef]

66. Frate, C.A.; Brannstrom, C. Stakeholder subjectivities regarding barriers and drivers to the introduction of utility-scale solar photovoltaic power in Brazil. Energy Policy 2017, 111, 346-352. [CrossRef]

67. dos Santos, L.L.C.; Canha, L.N.; Bernardon, D.P. Projection of the diffusion of photovoltaic systems in residential low voltage consumers. Renew. Energy 2018, 116, 384-401. [CrossRef]

68. Tranfield, D.; Denyer, D.; Smart, P. Towards a Methodology for Developing Evidence-Informed Management Knowledge by Means of Systematic Review. Br. J. Manag. 2003, 14, 207-222. [CrossRef]

69. Moher, D.; Liberati, A.; Tetzlaff, J.; Altman, D.G.; Group, T.P.; David, M.; Alessandro, L.; Jennifer, T.; Douglas, G.A.; The, P.G. Preferred reporting items for systematic reviews and meta-analyses:The PRISMA statement (Chinese edition). J. Chin. Integr. Med. 2009, 7, 889-896. [CrossRef]

70. Zambrano Leal, A. Sociedad de control y profesión docente. Las imposturas de un discurso y la exigencia de una nueva realidad. Educ. y Cult. 2012, 95, 45-52.

71. Shelley, M.; Krippendorff, K. Content Analysis: An Introduction to its Methodology; Taylor \& Francis, Ltd.: Oxfordshire, UK, 1984; Volume 79, ISBN 0761915451.

72. David, A.; Aaker, V.; Kumar, G.S.D. Marketing Research, 7th ed.; John Wiley \& Sons, Inc.: New York, NY, USA, 2001; ISBN 978-0471363408.

73. Kurdgelashvili, L.; Shih, C.H.; Yang, F.; Garg, M. An empirical analysis of county-level residential PV adoption in California. Technol. Forecast. Soc. Chang. 2019, 139, 321-333. [CrossRef]

74. Pearce, P.; Slade, R. Feed-in tariffs for solar microgeneration: Policy evaluation and capacity projections using a realistic agent-based model. Energy Policy 2018, 116, 95-111. [CrossRef]

75. Hopf, K.; Kormann, M.; Sodenkamp, M.; Staake, T. A decision support system for photovoltaic potential estimation. ACM Int. Conf. Proc. Ser. 2017, 3, 1-10.

76. Robinson, S.A.; Rai, V. Determinants of spatio-temporal patterns of energy technology adoption: An agent-based modeling approach. Appl. Energy 2015, 151, 273-284. [CrossRef]

77. La Monaca, S.; Ryan, L. Solar PV where the sun doesn't shine: Estimating the economic impacts of support schemes for residential PV with detailed net demand profiling. Energy Policy 2017, 108, 731-741. [CrossRef]

78. Arguello, A.; Lara, J.D.; Rojas, J.D.; Valverde, G. Impact of Rooftop PV Integration in Distribution Systems Considering Socioeconomic Factors. IEEE Syst. J. 2018, 12, 3531-3542. [CrossRef]

79. Bernards, R.; Verweij, R.; Coster, E.; Morren, J.; Slootweg, H. Application and evaluation of a probabilistic forecasting model for expected local PV penetration levels. CIRED—Open Access Proc. J. 2017, 2017, 2101-2105. [CrossRef]

80. Toroghi, S.H.; Oliver, M.E. Framework for estimation of the direct rebound effect for residential photovoltaic systems. Appl. Energy 2019, 251, 113391. [CrossRef]

81. Bernards, R.; Morren, J.; Slootweg, H. Development and Implementation of Statistical Models for Estimating Diversified Adoption of Energy Transition Technologies. IEEE Trans. Sustain. Energy 2018, 9, 1540-1554. [CrossRef]

82. Sultan, V.; Alsamani, B.; Alharbi, N.; Alsuhaibany, Y.; Alzahrani, M. A predictive model to forecast customer adoption of rooftop solar. In Proceedings of the 2016 4th International Symposium on Computational and Business Intelligence (ISCBI), Olten, Switzerland, 5-7 September 2016; pp. 33-44.

83. Candas, S.; Siala, K.; Hamacher, T. Sociodynamic modeling of small-scale PV adoption and insights on future expansion without feed-in tariffs. Energy Policy 2019, 125, 521-536. [CrossRef]

84. Wang, W.; Yu, N.; Johnson, R. A model for commercial adoption of photovoltaic systems in California. J. Renew. Sustain. Energy 2017, 9, 025904. [CrossRef] 
85. Letchford, J.; Lakkaraju, K.; Vorobeychik, Y. Individual household modeling of photovoltaic adoption. AAAI Fall Symp. Tech. Rep. 2014, FS, 19-23.

86. Dong, C.; Sigrin, B. Using willingness to pay to forecast the adoption of solar photovoltaics: A "parameterization + calibration" approach. Energy Policy 2019, 129, 100-110. [CrossRef]

87. Yamaguchi, Y.; Akai, K.; Shen, J.; Fujimura, N.; Shimoda, Y.; Saijo, T. Prediction of photovoltaic and solar water heater diffusion and evaluation of promotion policies on the basis of consumers' choices. Appl. Energy 2013, 102, 1148-1159. [CrossRef]

88. Parkins, J.R.; Rollins, C.; Anders, S.; Comeau, L. Predicting intention to adopt solar technology in Canada: The role of knowledge, public engagement, and visibility. Energy Policy 2018, 114, 114-122. [CrossRef]

89. Fleeson, W.; Jayawickreme, E.; Jones, A.B.A.P.; Brown, N.A.; Serfass, D.G.; Sherman, R.A.; Mestdagh, M.; Pe, M.; Pestman, W.; Verdonck, S.; et al. Feeling, caring, knowing: Different types of empathy deficit in boys with psychopathic tendencies and autism spectrum disorder. J. Child Psychol. Psychiatry 2010, 51, 1188-1197.

90. Malterud, K.; Siersma, V.D.; Guassora, A.D. Sample Size in Qualitative Interview Studies: Guided by Information Power. Qual. Health Res. 2016, 26, 1753-1760. [CrossRef] [PubMed]

91. Villareal, M.J.C.; Moreira, J.M.L. Household consumption of electricity in Brazil between 1985 and 2013. Energy Policy 2016, 96, 251-259. [CrossRef]

92. Holdermann, C.; Kissel, J.; Beigel, J. Distributed photovoltaic generation in Brazil: An economic viability analysis of small-scale photovoltaic systems in the residential and commercial sectors. Energy Policy 2014, 67, 612-617. [CrossRef]

93. Shahnia, F.; Majumder, R.; Ghosh, A.; Ledwich, G.; Zare, F. Voltage imbalance analysis in residential low voltage distribution networks with rooftop PVs. Electr. Power Syst. Res. 2011, 81, 1805-1814. [CrossRef]

94. Simpson, G.; Clifton, J. The emperor and the cowboys: The role of government policy and industry in the adoption of domestic solar microgeneration systems. Energy Policy 2015, 81, 141-151. [CrossRef]

95. Jager, W. Stimulating the diffusion of photovoltaic systems: A behavioural perspective. Energy Policy 2006, 34, 1935-1943. [CrossRef]

96. Rigo, P.D.; Siluk, J.C.M.; Lacerda, D.P.; Thomasi, V.; Rediske, G.; Rosa, C.B. Evaluation of the Success of a Small-Scale Photovoltaic Energy System. IEEE Lat. Am. Trans. 2019, 17, 1474-1481. [CrossRef]

97. Vale, A.M.; Felix, D.G.; Fortes, M.Z.; Borba, B.S.M.C.; Dias, B.H.; Santelli, B.S. Analysis of the economic viability of a photovoltaic generation project applied to the Brazilian housing program "Minha Casa Minha Vida". Energy Policy 2017, 108, 292-298. [CrossRef]

98. Zhang, X.; Shen, L.; Chan, S.Y. The diffusion of solar energy use in HK: What are the barriers? Energy Policy 2012, 41, 241-249. [CrossRef]

99. Tanaka, K.; Sekito, M.; Managi, S.; Kaneko, S.; Rai, V. Decision-making governance for purchases of solar photovoltaic systems in Japan. Energy Policy 2017, 111, 75-84. [CrossRef]

100. Pinto, J.T.M.; Amaral, K.J.; Janissek, P.R. Deployment of photovoltaics in Brazil: Scenarios, perspectives and policies for low-income housing. Sol. Energy 2016, 133, 73-84. [CrossRef]

101. de Souza, L.E.V.; Cavalcante, A.M.G. Towards a sociology of energy and globalization: Interconnectedness, capital, and knowledge in the Brazilian solar photovoltaic industry. Energy Res. Soc. Sci. 2016, 21, 145-154. [CrossRef]

102. Li, N.; Liu, C.; Zha, D. Performance evaluation of Chinese photovoltaic companies with the input-oriented dynamic SBM model. Renew. Energy 2016, 89, 489-497. [CrossRef]

103. Rosa, C.B.; Wendt, J.F.M.; Chaves, D.M.S.; Thomasi, V.; Michels, L.; Siluk, J.C.M. Mathematical modeling for the measurement of the competitiveness index of Brazil south urban sectors for installation of photovoltaic systems. Energy Policy 2020, 136, 111048. [CrossRef]

104. Muratori, M.; Roberts, M.C.; Sioshansi, R.; Marano, V.; Rizzoni, G. A highly resolved modeling technique to simulate residential power demand. Appl. Energy 2013, 107, 465-473. [CrossRef]

105. Hernández-Callejo, L.; Gallardo-Saavedra, S.; Alonso-Gómez, V. A review of photovoltaic systems: Design, operation and maintenance. Sol. Energy 2019, 188, 426-440. [CrossRef]

106. Rodrigues, S.; Torabikalaki, R.; Faria, F.; Cafôfo, N.; Chen, X.; Ivaki, A.R.; Mata-Lima, H.; Morgado-Dias, F. Economic feasibility analysis of small scale PV systems in different countries. Sol. Energy 2016, 131, 81-95. [CrossRef]

107. Sajjad, U.; Amer, M.; Ali, H.M.; Dahiya, A.; Abbas, N. Cost effective cooling of photovoltaic modules to improve efficiency. Case Stud. Therm. Eng. 2019, 14, 100420. [CrossRef] 
108. Li, Z.; Liu, X.; Tang, R. Optical performance of inclined south-north single-axis tracked solar panels. Energy 2010, 35, 2511-2516. [CrossRef]

109. Kreft, W.; Filipowicz, M.; Żołądek, M. Reduction of electrical power loss in a photovoltaic chain in conditions of partial shading. Optik (Stuttg) 2019, 202, 163559. [CrossRef]

110. Manju, S.; Sagar, N. Progressing towards the development of sustainable energy: A critical review on the current status, applications, developmental barriers and prospects of solar photovoltaic systems in India. Renew. Sustain. Energy Rev. 2017, 70, 298-313. [CrossRef]

111. Naik, S.G.; Khatod, D.K.; Sharma, M.P. Distributed Generation Impact on Distribution Networks: A Review. Int. J. Electr. Electron. Eng. 2012, 2, 68-72.

112. Rosas Luna, M.A.; Fontes Cunha, F.B.; De Miranda Mousinho, M.C.A.; Torres, E.A. Solar Photovoltaic Distributed Generation in Brazil: The Case of Resolution 482/2012. Energy Procedia 2019, 159, 484-490. [CrossRef]

113. Kumar Sahu, B. A study on global solar PV energy developments and policies with special focus on the top ten solar PV power producing countries. Renew. Sustain. Energy Rev. 2015, 43, 621-634. [CrossRef]

114. Bollinger, B.; Gillingham, K. Peer effects in the diffusion of solar photovoltaic panels. Mark. Sci. 2012, 31, 900-912. [CrossRef]

115. Fornara, F.; Pattitoni, P.; Mura, M.; Strazzera, E. Predicting intention to improve household energy efficiency: The role of value-belief-norm theory, normative and informational influence, and specific attitude. J. Environ. Psychol. 2016, 45, 1-10. [CrossRef]

116. Rai, V.; Reeves, D.C.; Margolis, R. Overcoming barriers and uncertainties in the adoption of residential solar PV. Renew. Energy 2016, 89, 498-505. [CrossRef]

117. Nolan, J.M.; Schultz, P.W.; Cialdini, R.B.; Goldstein, N.J.; Griskevicius, V. Normative social influence is underdetected. Personal. Soc. Psychol. Bull. 2008, 34, 913-923. [CrossRef] [PubMed]

118. Duan, H.; Zhang, G.; Wang, S.; Fan, Y. Peer interaction and learning: Cross-country diffusion of solar photovoltaic technology. J. Bus. Res. 2018, 89, 57-66. [CrossRef]

119. Ma, C.; Menke, J.H.; Dasenbrock, J.; Braun, M.; Haslbeck, M.; Schmid, K.H. Evaluation of energy losses in low voltage distribution grids with high penetration of distributed generation. Appl. Energy 2019, 256, 113907. [CrossRef]

120. Reames, T.G. Targeting energy justice: Exploring spatial, racial/ethnic and socioeconomic disparities in urban residential heating energy efficiency. Energy Policy 2016, 97, 549-558. [CrossRef]

121. Faiers, A.; Neame, C. Consumer attitudes towards domestic solar power systems. Energy Policy 2006, 34, 1797-1806. [CrossRef]

122. Battu, H.; Bender, K.A. Educational mismatch in developing countries: A review of the existing evidence. In The Economics of Education; Elsevier Ltd.: Cambridge, MA, USA, 2020; pp. 269-289.

123. Gadenne, D.; Sharma, B.; Kerr, D.; Smith, T. The influence of consumers' environmental beliefs and attitudes on energy saving behaviours. Energy Policy 2011, 39, 7684-7694. [CrossRef]

124. Chen, K.K. Assessing the effects of customer innovativeness, environmental value and ecological lifestyles on residential solar power systems install intention. Energy Policy 2014, 67, 951-961. [CrossRef]

125. Brum Rosa, C.; Mairesse Siluk, J.C.; Michels, L. Proposal of the Instrument for Measuring Innovation in the Generation Photovoltaics. IEEE Lat. Am. Trans. 2016, 14, 4534-4539. [CrossRef]

126. Liobikienè, G.; Liobikas, J.; Brizga, J.; Juknys, R. Materialistic values impact on pro-environmental behavior: The case of transition country as Lithuania. J. Clean. Prod. 2020, 244, 118859. [CrossRef]

(C) 2020 by the authors. Licensee MDPI, Basel, Switzerland. This article is an open access article distributed under the terms and conditions of the Creative Commons Attribution (CC BY) license (http://creativecommons.org/licenses/by/4.0/). 